Faculty Scholarship

2011

\title{
On Nontraditional Trademarks
}

Kenneth L. Port

Mitchell Hamline School of Law, ken.port@mitchellhamline.edu

Publication Information

38 Northern Kentucky Law Review 1 (2012)

\section{Repository Citation}

Port, Kenneth L., "On Nontraditional Trademarks" (2011). Faculty Scholarship. Paper 235.

http://open.mitchellhamline.edu/facsch/235

This Article is brought to you for free and open access by Mitchell Hamline Open Access. It has been accepted for inclusion in Faculty Scholarship by an authorized administrator of Mitchell Hamline Open Access. For more information, please contact sean.felhofer@mitchellhamline.edu.

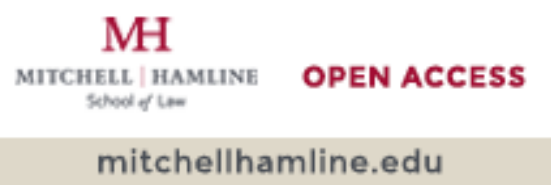




\title{
On Nontraditional Trademarks
}

\begin{abstract}
This piece regards nontraditional trademarks like sound, color, scent or even the vertical opening motion of a Lamborghini car door. The protection of trademarks has, historically, walked a fine balance. Naturally, as a society, we want to protect trademarks so that transaction costs are lowered as purchasers make a quick and easy purchasing decision. You see Tide, you know Tide, you buy Tide. However, the protection of nontraditional trademarks upsets this fine balance. If we go too far in the protection we grant unwarranted monopolies to companies to stifle the precise competition the law was meant to encourage. Sometimes, we do not have to protect a trademark claimant to recognize the savings in search costs. In fact, nontraditional trademarks are ornamental, at best, and, at worst, a horrible distraction from the larger job of substantive harmonization so that the transactions costs might be lessened for all companies around the world.
\end{abstract}

This article traces the origins of this protection and concludes that nothing in our history predicts or requires this protection. One Supreme Court decision in 1995 open the floodgates for trademark application activity, but litigation rates did not, correspondingly, increase. I relied on a study I did of all 2,762 reported trademarks decisions from the inception of the Lanham Act (the US trademark law) through 2007. I coded every case. The numbers are reported in this article. Trademark registration activity is still very small and litigation activity is near nonexistent.

However, the United States requires potential trading partners to protect nontraditional trademarks or we will not enter into bi-lateral trade agreements. We have encouraged the World Intellectual Property Organization to conduct a massive study on the protection of nontraditional marks. Based on this flawed study, some countries are now contemplating amending their trademark laws to explicitly recognize nontraditional trademarks.

This is a cause without an objective. People generally believe that America routinely protects nontraditional trademarks. My data indicates that this is not the case. Then, countries are attempting to harmonize to the standard of protecting nontraditional trademarks thinking that is required in the United States when it is not.

In the end, this provides an amazing distraction to the greater goal of harmonizing trademark laws. Civil Law countries believe they are harmonizing to an international standard of trademark law when that standard is a fiction created by the United States (without malice). Instead of working on far more important goals that have remained elusive for 120 years and without concern to harmonizing the underlying theory of trademark protection, countries are focusing efforts on protecting the motion of a Lamborghini door.

My argument is that this is unfortunate. We should understand the distinctions between the two systems and work to close that gap in a meaningful way. No matter how many countries protect the motion of a Lamborghini door opening, without harmonizing the underlying theory and without addressing real issues, real harmonization will remain elusive

\section{Keywords}

Trademark, Non-Traditional Trademark, Color Mark, Sound Mark, Scent Mark

\author{
Disciplines \\ Intellectual Property Law
}




\title{
ON NONTRADITIONAL TradEMARKS
}

\author{
Kenneth L. Port
}

\section{INTRODUCTION}

International substantive trademark law harmonization has been an abject failure. This failure is manifested in the inconsistent treatment of nontraditional trademarks. This article exposes the perceived broad protection of nontraditional trademarks for the great deception that it is. By allegedly protecting nontraditional trademarks, the United State renders true trademark harmonization impossible. The United States itself and commentators go too far in expressing this protection. In fact, nontraditional trademark protection is extremely limited, very rare and almost never enforced. Yet, the United States requires trading partners to protect nontraditional trademarks as if it is a mainstay of trademark jurisprudence in the United States, when it is not. The World Intellectual Property Organization (WIPO) and the international community are in the process of harmonizing to this fictitious standard. This will render real efforts at genuine trademark harmonization even more difficult to attain.

Part II of this article describes the setting of nontraditional trademark jurisprudence in the United States. It concludes that Americans boast of protection of odd appellations of source, but in reality, it is very infrequently accomplished and then only at great expense.

Part III traces the etymology of the words "symbol" and "device", the precise statutory terms upon which the protection of nontraditional trademarks rests.

Parts IV - XI address each known type of nontraditional trademark. Specific data is provided to conclude that color and sound make up virtually all nontraditional trademarks and that the data does not support claims of nontraditional trademarks playing a meaningful role in United States trademark jurisprudence.

Part XII presents a very brief explication of the Common Law of trademarks compared to the Civil Law of trademarks so that one can see the disparate views of trademark protection.

Part XIII provides a normative attack on the protection of nontraditional trademarks and concludes that, in almost all cases, they do not operate as indicators of source and therefore should not be protected.

* Professor of Law and Director, Intellectual Property Institute, William Mitchell College of Law. I am indebted to Madeline Bowie (2010) for her research assistance. I am also grateful to Jim Baker, Adjunct Professor of Law, William Mitchell College of Law and the members of my Contemporary Issues in IP class for their input and feedback of an earlier draft of this article. I am also grateful to Neal Axton, Reference Librarian, William Mitchell College of Law, for his research and input. 
Part XIV concludes that nontraditional trademarks do not play the major role in American trademark jurisprudence that some want us to believe. There has been registration activity but no corresponding reported enforcement activity. As such, much is made of nontraditional trademark protection but it is a vacuous promise. The world should not harmonize to the vacuous. If we harmonize, it should be to a standard that will be effective in lowering trade barriers, increasing the free flow of goods and services, and generally making the lives of trademark holders easier, not to a fictitious standard that is almost entirely meaningless.

\section{CONTEXT}

"Nontraditional trademarks," include sensory marks such as sound, color, scent, taste, and tactile marks, and also holographic marks or even the motion of a product. They play an increasingly important role in the plan of some to engage in "extreme branding." " Nontraditional indicators of source purportedly become a valid trademark when they are or become distinctive of the good or service on which they are used and, in the minds of the consumers, come to identify a consistent source or origin for that good or service ${ }^{2}$ and can be represented graphically. Nontraditional trademarks fall into the larger category of trade dress discussed in the Qualitex Co. v. Jacobson Products Co., 514 U.S. 159 (1995) decision and, as such, must have secondary meaning to be protected. ${ }^{3}$ The Qualitex case itself is said to be a "stunning breakthrough for nontraditional trademarks." 4

In fact, United States Patent and Trademark Office (PTO) application statistics indicate that there were only 93 nontraditional trademarks on record

1. See, e.g., EXTREME BrANDING, http://www.extremebranding.com (last visited Sept. 22, 2011). This phrase itself is a purported trademark, although unregistered. This term was recently coined by Nick Pisarsky, Note, PoTAYto-PoTAHto-Let's Call the Whole Thing Off: Trademark Protection of Product Sounds, 40 CONN. L. REV. 797, 800 (2008). A trademark application for EXTREME PERSONAL BRANDING was received by the United States Patent and Trademark Office (PTO) but was soon abandoned. See United States Patent and Trademark Office, Leg Up Marketing, LLC, Serial No. 78847574 (indicating the mark has been abandoned) available at $\mathrm{http}: / /$ tarr.uspto.gov/servlet/tarr?regser=serial\&entry $=78847574$.

2. Qualitex Co. v. Jacobson Prods. Co., Inc., 514 U.S. 159 (1995).

3. Fabrication Enters., Inc. v. Hygenic Corp., 64 F.3d 53 (2d Cir. 1995) (color scheme on rubber bands to denote resistance has acquired secondary meaning and is protectable); Mana Prods., Inc. v. Columbia Cosmetics Mfg., Inc., 65 F.3d 1063 (2d Cir. 1995) (no secondary meaning for black compacts in ordinary shapes used within the industry as a whole); Knitwaves Inc. v. Lollytogs Ltd., 71 F.3d 996 (2d Cir. 1995) (ecological design on sweaters is distinctive). As of yet, an unanswered question is whether product packaging that amounts to a nontraditional trademark could be inherently distinctive and protectable without possessing secondary meaning. In WalMart Stores, Inc. v. Samara Bros., Inc., 529 U.S. 205 (2000), the Supreme Court held that product packaging could be inherently distinctive but not product design. That case is silent on the nontraditional trademark discussed herein.

4. Jerome Gilson \& Anne Gilson LaLonde, Cinnamon Buns, Marching Ducks and CherryScented Racecar Exhaust: Protecting Nontraditional Trademarks, 95 TRADEMARK REP. 773, 782 (2005). 
prior to the Qualitex decision. After the Qualitex decision published on March 28,1995 , there have been 688 trademark applications filed for nontraditional trademarks. ${ }^{6}$ That is, in the first 48 years of the existence of the Lanham Act, there were 93 nontraditional trademarks filed (1.93 per year). In the 14 years since the Qualitex decision, there have been 688 trademark applications for nontraditional trademarks (approximately 49 a year). ${ }^{8}$ This is an explosion of interest in nontraditional trademarks.

Contrary to the claims of some that Qualitex resulted in a "stunning breakthrough," in fact, Qualitex did not have the same impact on the number of reported cases involving nontraditional trademarks. ${ }^{10}$ In the 48 years before Qualitex, there were 20 reported cases; in the 14 years since Qualitex (for which there is data), there have been 15 reported cases. ${ }^{\text {. }}$ Per year that amounts to a doubling of the number of cases (pre-Qualitex: 42 per year, post-Qualitex: 1.07 per year); however, as these numbers remain around one per year, it is hard to see this as a "stumning breakthrough" and certainly not the exponential increase that there was in applications. 12

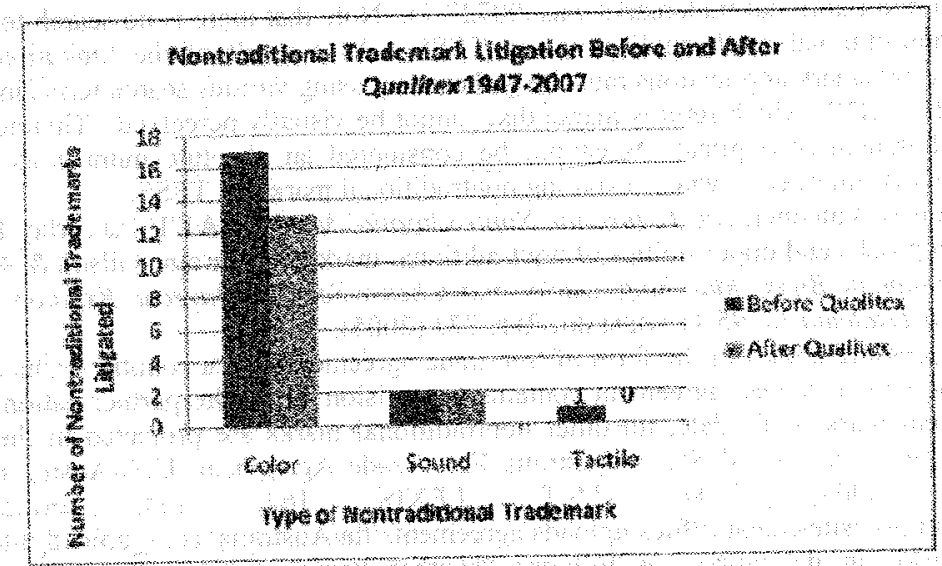

Even so, nontraditional trademarks still make up an infinitesimally small portion of all trademark applications or registrations. ${ }^{13}$ In August of 2009 ,

5. See infra app. E.

6. See infra app. E.

7. See infra app. E.

8. See infra app. E.

9. Gilson \& LaLonde, supra note 4.

10. Mitchell Study on Trademark Litigation, Graph A: Total Number of Reported Cases Per Year, http//www.wmitchell.edu/intellectual-property/fles/WM-TMStudy-GraphA.pdf.

11. Id.

12. Source of graph: http://www wmitchelledu/intellectual-property/?page-321 \&Mitchell+ Studyt on +Trademark+Litigation.

13. See infra note 14 (comparing number of nontraditional trademarks to number of total trademarks). 
approximately $0.01504 \%$ of all trademark applications on record with the PTO were for nontraditional trademarks. ${ }^{14}$

Yet, much is made of this ability in the United States to register nontraditional trademarks ${ }^{15}$ and the United States has even placed pressure on other countries to expand the scope of other countries' trademark laws to include the protection of nontraditional trademarks. ${ }^{16}$ The Singapore Treaty on Trademarks in 2006 was the first treaty to explicitly recognize nontraditional trademarks although it also stated that signatory states are under no obligation to adopt "new types" of trademarks. ${ }^{17}$ This interest in and support for

14. A search on the Trademark Electronic Search System (TESS) maintained by the USPTO, for "(live)[LD] or (dead)[LD]" on August 28, 2009 returned 5,192,791 records. This is the total number of trademark applications on file with the PTO as of that date. The number of nontraditional trademarks gathered from TESS yielded 781 applications as of August 28, 2009. Therefore, the percentage of nontraditional trademarks on file with the PTO in any capacity, be they applications, registrations, abandoned or canceled, is only $0.01504 \%$. For a similar search done in 2006, see Nick Pisarsky, Note, PoTAYto-PoTAHto-Let's Call the Whole Thing Off: Trademark Protection of Product Sounds, 40 CONN. L. REV. 797, 803 n.28 (2008) (showing that the percent of nontraditional trademarks was $.00727 \%$ ). Note that there is no search term that will search all nontraditional mark applications in TESS. As a result of the limitations of TESS nontraditional trademark applications must be gathered by using various search terms in addition to searching "('6')[MD]", which returns marks that cannot be visually perceived. Therefore, the 780 nontraditional trademark applications cannot be considered an absolute number as there is an unquantifiable margin of error when searching nontraditional marks on TESS.

15. Russell H. Falconer, Big Future for Nontraditional Marks, NAT'L L.J., May 18, 1998, at C28 (discussing risks and opportunities of nontraditional mark use); Jerome Gilson \& Anne Gilson LaLonde, Cinnamon Buns, Marching Ducks and Cherry-Scented Racecar Exhaust: Protecting Nontraditional Trademarks, 95 TRADEMARK REP. 773 (2005).

16. This pressure comes in the form of free trade agreements. If a country wants a free trade agreement, the United States' agreement contains a provision to require partner nations to protect sound and scent marks. To date, no other nontraditional marks are protected in the free trade agreements. See, e.g., United States-Australia Free Trade Agreement, U.S.-Austl., art. 17.2(2), May 18, 2004, 2004 U.S.T. LEXIS 162, 234, available at http://www.ustr.gov/sites/default/files/uploads/agreements/fta/Australia/asset_upload_file469_5141 .pdf which reads in its entirety as follows: "Neither Party may require, as a condition of registration, that marks be visually perceptible, nor may a Party deny registration of a mark solely on the ground that the sign of which it is composed is a sound or a scent.". The free trade agreements with 13 other nations contain similar requirements. See generally, Free Trade Agreements, Office of the United States Trade Representative http://www.ustr.gov/tradeagreements/free-trade-agreements (providing texts of other free trade agreements). The International Trademark Association (NNA) has its own model free trade agreement that requires countries to protect sound, single colors, and three-dimensional shape marks. See Model Free Trade Agreement Proposals Intellectual Property Rights: Trademark Law, http://www.inta.org/downloads/tap_modelfreetrade.pdf (expressing intent to protect sound, single color, and three-dimensional shape marks).

17. Singapore Treaty on the Law of Trademarks, R. 3(5) available at http://www.wipo.int/edocs/mdocs/mdocs/en/tlt_r_de/tilt_r_dc_30.pdf ("[Hologram Mark, Motion Mark, Color Mark, Position Mark] Where the application contains a statement to the effect that the mark is a hologram mark, a motion mark, a color mark or a position mark, a Contracting Party may require one or more reproductions of the mark and details concerning the mark, as prescribed by the law of that Contracting Party"). The United States position on nontraditional trademarks seems to be that the PTO will support international efforts in this regard because there is so little else where cooperation seems possible at this given moment. 
nontraditional trademarks is paying off as Japan has moved to adopt nontraditional trademarks and even WIPO's Standing Committee on the Law of Trademarks, Industrial Designs and Geographic Indications has recently waken this up in the form of a major study and report. At least one entire book was published by the International Trademark Association that gives the implication that protecting nontraditional trademarks is a common, routine and a frequent affair. ${ }^{19}$

In fact, the registration of nontradicional marks in the United States is a very difficult, time consuming and expensive endeavor. Nontraditional tradernark registrations constitute a minute fraction of all registered trademarks in the United States. ${ }^{20}$ Furthermore, nontraditional trademarks are extremely diffoult to enforce. Of the 2,762 reported Lanham Act cases since 1947, the inception date of the Act, $35(1.27 \%)$ were cases regarding a nontraditional trademark and of those $13(37 \%)^{21}$ prevailed when the national average over the 60 years of the Lanham Act is that the plaintiff prevaled $50 \%$ of the time. ${ }^{22}$

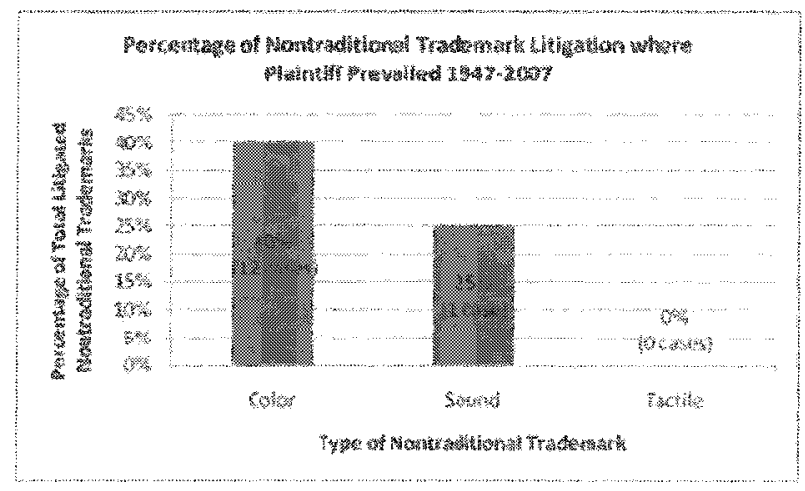

Some of the more well known registered nontraditional marks inchude the roar of the lion in the initial credit scenes of a movie (owned by MGM), ${ }^{23}$

18. Wortd Intellectual Property Organization [WPO], Standing Committee on the Law of Trademarks, Industrial Designs and Geographical Indications: Summary of Repties to the Questionnaire on Trademark Law and Praciice (SCT/11/6), \$CT/14/5 Rev. (Nov. 1, 2005) available at http://www.wipo.int/edocs/mdocs/scten/sct $14 / \mathrm{sct}_{\mathrm{m}} 14 \mathrm{~m}_{\mathrm{m}} \mathrm{s} \mathrm{rev}$.pdf.

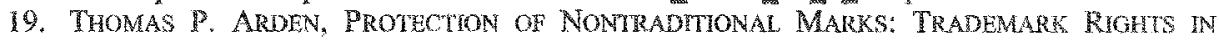
Soundos, Scents, Colors, MOtrons And PronUCt Design IN The U.S. (2000).

20. An August 28, 2009 search on TESS for " $\mathrm{RN}>$ "0" returned 2,968,267 recorls. "This is the total number of registered trademarks on file with the PTO as of that date. The number or nortraditional trademark registrations gathered from TESS was 452 as of August 28,2009 . Therefore, the percentage of nontraditional trademark registrations on file with the PTO is a mere $0.015227 \%$

21. Mitchell Study on Trademark Litigation, htp:/www.wmitchelledu/ntellectual. property/?page $=321$ \& Mitchell + Study ton + Trademark + Litigation.

22. See Mitchell Study on Trademark Litigation, Graph B: Total Infringement Clains Established/Not Established (2008), htto:/www.wmitchell,edu/intellectual-propery/files/WMTStudy-GraphB.pdf (comparing number of established claims to not established claims).

23. Metro-Goldwyn-Mayer Lion Corp., Reg. No. 1,395,550 ("The tuark comprises a lion roaring."). 
plumeria-scented yarn that came in a sealed kit to knit a skunk (well-known, that is, among intellectual property people), ${ }^{24}$ or even the sound of a Harley Davidson motorcycle while on idle. ${ }^{25}$ Some of the less known registered nontraditional trademarks include the vertical opening motion of Lamborghini car door ${ }^{26}$ or the vertical spray of water from the back of a Yamaha personal watercraft. ${ }^{27}$ Applications for registration include some unusual things including the DNA sequence for futurist Frank Ogden ${ }^{28}$ or anthropomorphic wilted flowers yelling insults. $^{29}$

Nontraditional marks may be registered in the United States because the Lanham Act states that "any word, name symbol or device" that is used on or in connection with some good or service may be registered if it has secondary meaning. ${ }^{30}$ The United States Supreme Court has interpreted this use of "any" as actually meaning "any." 31 Therefore, the mere color alone of a green/gold press

24. In re Clarke, 17 U.S.P.Q.2d (BNA) 1238 (T.T.A.B. 1990); See also Celia Clarke, Reg. No. $1,639,128$ ("The mark is a high impact, fresh, floral fragrance reminiscent of plumeria blossoms.").

25. Harley-Davidson, Inc., Serial No. 74,485,223 ("The mark consists of the exhaust sound of applicant's motorcycles, produced by V-Twin, common crankpin motorcycle engines when the goods are in use.").

26. Automobile Lamborghini Holding S.p.A., Reg. No. 2,793,439 ("The mark consists of the unique motion in which the door of a vehicle is opened. The doors move parallel to the body of the vehicle but are gradually raised above the vehicle to a parallel position.").

27. Yamaha Hatsudoki Kabushiki Kaisha, U.S. Patent No. 1,946,170 ("The mark is comprised of a three dimensional spray of water issuing from the rear of a jet propelled watercraft and is generated during the operation of the watercraft."). See generally, Lesley Matty, Note, Rock, Paper, Scissors, Trademark? A Comparative Analysis of Motion as a Feature of Trademarks in the United States and Europe, 14 CARDOZO J. INT'L \& COMP. L. 557 (2006) (discussing motion marks). A personal watercraft is more commonly called a "jet ski." However, JET SKI is actually the registered trademark of Kawasaki Heavy Industries, Ltd., U.S. Patent No. 1,394,547 (filed Jan. 20, 1984). Of course, this is not to be confused with Honda's AQUATRAX (U.S. Patent No. 2,737,518 (filed August 9, 2000).) or Bombardier Recreational Products' SEA-DOO (U.S. Patent No. 3,705,331 (filed Feb. 3, 2005)).

28. Frank Ogden's trademark application claimed its identification of goods as follows: "DNA GENE SEQUENCE TO PRODUCT [sic] FRANK OGDEN OR OTHER PROSPECTIVE HUMANS, CLONES, SURVIVAL MACHINES, OR FUTURISTIC ANIMALS THAT ARE USED TO CREATE IDEAS." U.S. Patent Serial No. 76,016,924 (filed April 3, 2000) (abandoned Jan. 21, 2002). Frank Ogden maintains a web site at http://www.drtomorrow.com. Mr. Ogden's registered trademark for Dr. TOMORROW was cancelled in 2004. U.S. Patent Serial No. $74,274,318$ (filed May 11, 1992) (cancelled June 12, 2004). When asked, Frank Ogden responded that the reason he attempted to register his own DNA sequence was because "I THOUGHT THAT JUST THE LOOKING AT A PERSON AND BE WILLING TO PENETRATE THEIR DNA WOULD REMOVE A LOT OF CONTROL OVER ANY TAXPAYER. I WANTED TO GET THERE BEFORE SOME BUREAUCRAT GOT A BILL PASSED FOR THAT CONTROL." Email to Frank Ogden (July 29, 2009) (on file with author).

29. U.S. Patent Serial No. 77,621,516 (filed Nov. 25, 2008) (abandoned Mar. 2, 2010). See also Teleflora Brings Sassy Talking Flowers Super Bowl XLIII, http://www.youtube.com/watch?v=Oy0UN7OI-cg (video of the use of this mark in an advertisement that aired during Super Bowl in 2009).

30. 15 U.S.C. $\$ 1127$ (2006); Qualitex Co. v. Jacobson Prods. Co., Inc., 514 U.S. 159, 162-64 (1995).

31. Qualitex, 514 U.S. at 162. 
pad used in the laundry business was found to be a valid trademark. ${ }^{32}$ That is, any "symbol or device" 33 that identifies source is a valid trademark in the United States if it has secondary meaning.

This article argues that nontraditional trademarks should be denied registration and be deemed unenforceable. ${ }^{34}$ Nontraditional trademarks are functional. Nontraditional trademarks are subjective; what one person perceives of the sensory mark is not what others perceive. As such, there can be no reliable test for when the nontraditional mark is infringed or diluted. Courts know this. Nontraditional marks succeed in trademark infringement or dilution causes of action only $37 \%$ of the time ${ }^{35}$ while trademark holders prevail nearly $50 \%$ of the time in all reported trademark causes of action since $1947 . .^{36}$

More importantly, the substantive harmonization of trademark laws around the world, a contentious issue for 120 years, is proceeding. However, the substantive harmonization is to an odd standard. There now is a movement among WIPO countries to harmonize to the standard of protecting nontraditional trademarks as opposed to preventing nontraditional trademarks from becoming protectable. ${ }^{37}$ This is an odd movement because there have been so few significant nontraditional trademark registrations in the United States and so few nontraditional trademarks that are successfully enforced. Even if harmonized, these numbers are so small that they could not possibly make any difference whatsoever. Furthermore, this doctrinal harmonization will not be effective because the underlying jurisprudence of trademark protection between the United States and Civil Law countries will remain distinct.

Therefore, the goal of harmonization, which is to some degree to create approximations between two or more systems to reduce transaction costs, will not be recognized because the theory on which protection is based will remain distinct and the numbers of possible nontraditional trademarks remain extremely

32. Id. at 166 .

33. Id. at $162-63$.

34. For purposes of this article, as product design or product configuration marks have become mainstream, trade dress marks will not be considered nontraditional.

35. See Mitchell Study on Trademark Litigation, http://www.wmitchell.edu/intellectualproperty/?page $=321 \&$ Mitchell + Study+on + Trademark + Litigation (compiling and organizing reported trademark cases).

36. Mitchell Study on Trademark Litigation, Graph B: Total Infringement Claims Established/Not Established, http://www.wmitchell.edu/intellectual-property/files/WM-TMStudyGraphB.pdf.

37. World Intellectual Property Organization, Member States Agree to Move Ahead With Efforts To Harmonize Trademark Law, http://www.wipo.int/pressroom/en/ html.jsp?file=/redocs/prdocs/en/2001/wipo_upd_2001_154.html; World Intellectual Property Organization, WIPO Member States Agree to Move Forward With Harmonization of Trademark Law, http://www.wipo.int/pressroom/en/html.jsp?file=/redocs/prdocs/en/2002/wipo_upd_2002 _169.html; World Intellectual Property Organization, Member States Address Non-Traditional Marks, Advance Work on Industrial Designs, http://www.wipo.int/pressroom/en/articles/ 2010/article_0024.html. 
small. As such, this harmonization is doomed to fail as it is numerically infinitesimal and a misguided and mistrusted jurisprudence.

The United States is the only country in the world that protects "any" word, name or even device as trademarks. Although Japan is considering legislation that would extend trademark protection to nontraditional marks, ${ }^{38}$ no other country has gone so far as to pass express legislation in this manner. ${ }^{39}$ The fact that the United States' system of trademark jurisprudence conceptually supports and validates nontraditional trademarks is a manifestation of how far the United States is, conceptually, from the trademark laws of the Civil Law countries. That is, by protecting "any" symbol or device, the United States trademark jurisprudence is out of sync with the rest of the world. Although some countries are attempting to doctrinally harmonize their trademark law to the peculiar standard of protecting nontraditional trademarks, they will not succeed in harmonizing trademark law in this area. There are so few nontraditional trademarks that providing them protection will not affect anything in the larger universe of trademark jurisprudence.

This is significant because most of the people on the planet do not live in Common Law jurisdictions. In fact, as the following graphs ${ }^{40}$ make explicit, the vast majority of the world population lives in either strict Civil Law jurisdictions or in some combination. Only a third of the world's population lives in strictly Common Law countries, and even then registration plays a significant role in trademark right generation. Less than a third of all countries are Common Law nations.

38. ATARashi TaIPUNo Shyohyouni Kansuru ChOSAKenkyo HoKoKusho [White PAPER ON New Types of Trademarks, Japanese Patent OfFice, Institute of INTELlectual Property] (2008), available at http://www.jpo.go.jp/shiryou/toushin/chousa/pdf/zaisanken/ 1907atarashiitype_honpen.pdf.

39. Kevin K. McCormick, "Ding" You are Now Free to Register Sound, 96 TRADEMARK REP. $1101,1105-1109$ (2006) (comparing United States' broad trademark protection to the European Union). See World Intellectual Property Organization [WIPO], Standing Committee on the Law of Trademarks, Industrial Designs and Geographical Indications, Summary of Replies to the Questionnaire on Trademark Law and Practice (SCT/11/6), SCT/14/5 Rev. (Nov. 1, 2005) (organizing and summarizing responses of member nations to trademark questionnaire) available at http://www.wipo.int/edocs/mdocs/sct/en/sct_14/sct_14_5_rev.pdf.

40. Central InTELLIGENCE AgenCy, THE CIA WORLD FACTBOOK (2008). 


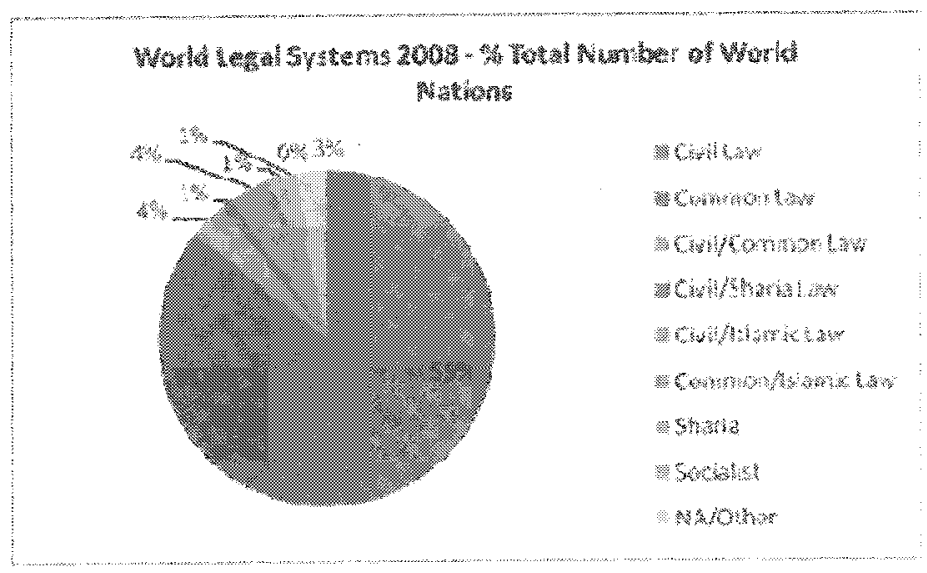

In the United States, the tradenark right is a right of exclusion. ${ }^{41}$ One is allowe to exclude others only to the extent one uses a mark and for long as one uses the mark, In the Civil Law world, a trademark is much more. In countries like France, ${ }^{43}$ Gemany ${ }^{44}$ or Japan, ${ }^{45}$ the registered rademark is property. ${ }^{46}$ In these countries, a trademark is, by defintion, a registered mark. ${ }^{47}$ Registration in Civil Law countries is harder to obtain than in the United States and registered marks are more difficult to lose. As the Civil Law of trademarks treats the trademark as property and in the United States it is a mere right of exclusion, in

41. Coll. Say. Bank v. Fla. Prepaid Postsecondary Educ. Expense Bd., 527 U.S. 666, 673 (1999) (quoting K Matt Corp. v. Cartier, hwe, 485 U.S. 176, 185-86 (1988)). See generally Keith M. Stolte, How Early Did Anglo-Amenican Tradench Law Begin? An Answer to Schenter's Comudrum, 8 FondHAM INTEZ, PROP. MEDLA \& ENT. L.J. 505, 506n07 (1998) (providing a comprehensive review and analysis of the "oldest reported trademark case in Anglo-American law," which provides a bridge to medieval protection of guild narks and common law courts narks).

42. 15 U.S.C. 1127 (2006); K Mart Corp. v. Cartier, Lnc., 486 U.S. 281, 325-28 (1988).

43. Terance 3. Keenan, American and Fronch Perspectives on Trademark Keying: The Courts Ieave Businesses Searching for Anwers, 2 SHDLER J. L. CoM. \& TECH. 14, P24 P25 (2005).

44. Rudolf Rayle, The Trend Towards Enhancing Trademank Owers' Rights-A Comparative Study of U.S and German Trodemark Low, 7 J. INTEL. PROP. L. 227, 270 (2000) ("6trademarks in Gervany are property").

45. KERNEH L. PORT, TRADRMARE AND UNFAIR COMPLTTION LAW AND POLICY IN JAPAN 5-6 $(2007)$.

46. Section 4 of Council Regulation that established the CTM system is titled "Community Tradenarks as Objacts of Property" and Article 19 of the Regulation gives in rem jurisdiction over redemarks. Council Regulation 40/94, 1994 O.J. (L.11) 1.

47. In Japan, for example, Article 18 of the Trademark Act says that the trademark right subsists only upon registration. Tradenark Act, Law No. 127 of 1959, art. 18 (Japan), translated and available at htp:/www.japaneselawtranslation.go.jp/law/detall/?id=45\&vm=048re=02. See also Max Veri, A Tradenark Visa -a Aspects of Thtemational Tradenark Use and Protection, 88 I. PAT. \& TRADMARK OFE. SOC'Y 847, 848 (2006) ("[t]he tenet of the Civil law system [is] that there are no trademark rights without a trademark registration"). See generolly KENNETH L. FoRT, TRADFMARK AND UNFAR CONPETTHON LAW AND POLCY IN JAPAN $77-81$ (2007)(discaissing McDonald"s late trademark registration and protection in Japany. 
the 125 years since the Paris Convention, ${ }^{48}$ the world has made nearly no progress in harmonizing substantive trademark law. This lack of progress has not been because countries were not trying.

In fact, much effort has been given to the job of harmonizing trademark laws. $^{49}$ Success has been elusive, ${ }^{50}$ however, because the Civil Law of trademarks is so conceptually disparate from the Common Law of trademarks. To be meaningful, in harmonizing trademark law, both the theory and the doctrine of trademark law must be harmonized. ${ }^{51}$ To merely adopt, for example, a trademark system where rights are created by registration, as in the Civil Law world, not by use, would be unconstitutional in the United States. That is, it would take a constitutional amendment for the United States to grant rights based on registration, not on use.

In fact, there are major and much more meaningful issues in substantive trademark harmonization other than, for example, whether Japan will allow the registration of the motion of a Lamborghini door. The world cannot agree on when trademark rights are created. Is it upon use or upon registration? The world cannot agree on when a trademark is or is not diluted. The world cannot agree on what constitutes a famous mark and to what degree such a famous mark

48. Paris Convention for the Protection of Industrial Property, Mar. 20, 1883, 21 U.S.T. 1583, 828 U.N.T.S. 305.

49. See Edward Grosek, The Multilateral Agreements that Protect Trademarks and Marks that Indicate Origins of Source, 82 J. PAT. \& TRADEMARK OFF. SOC'Y 471 (2000) (compiling international trademark law resources); Alejandro Guanes-Mersan, A General Comparative Overview of Trademark Regulations Between the United States and Paraguay, 16 ARIZ. J. INT'L \& COMP. LAW 775 (1999) (discussing international trademark laws as they affect the United States and Paraguay); Marshall A. Leaffer, The New World of International Trademark Law, 2 MARQ. INTELL. PROP. L. REV. 1 (1998) (discussing harmonization of trademark laws); Jeffrey M. Samuels \& Linda B. Samuels, The Changing Landscape of International Trademark Law, 27 GEO. WASH. J. INT'L L. \& ECON. 433 (1994) (analyzing international treaties and their impact on national trademark laws).

50. Two of the most significant attempts at harmonizing trademark law came in the form of the Madrid Protocol and the TRIPs Agreement. See generally Steven Andreacola, Part Six: Trademarks in the International Arena: International Conventions and Agreements: Lanham Act Meets Madrid Protocol and Trademark Law Treaty: The Application Process, 12 J. CONTEMP. LEGAL Issues 489 (2001); Thies Bosling, Securing Trademark Protection in a Global EconomyThe United States' Accession to the Madrid Protocol, 12 U. BALT. INTELL. PROP. L.J. 137 (2004); Charles Samuels, A Big Push Toward E-Government: The United States Patent and Trademark Office and the Implementation of the Madrid Protocol, 14 ALB. L.J. SCI. \& TECH. 535 (2004); Jeffrey M. Samuels \& Linda B. Samuels, The Changing Landscape of International Trademark Law, 27 GEO. WASH. J. INT'L L. \& ECON. 433 (1994) (each reviewing the Madrid Protocol) and Joanna Schmidt-Szalewski, The International Protection of Trademarks After the TRIPS Agreement, 9 DUKE J. COMP. \& INT'L L. 189 (1998) (reviewing TRIPs Agreement).

51. Timothy W. Blakely, Beyond the International Harmonization of Trademark Law: The Community Trade Mark as a Model of Unitary Transnational Trademark Protection, 149 U. PA. L. REV. 309, 313 (2000) (explaining two inherent weaknesses in harmonization are (1) the differences in legislative processes and (2) "inconsistencies in the meaning and application of the law"). 
deserves cross border protection. ${ }^{52}$ The world is morbidly fixed to the notion of territoriality of trademark laws. All these issues are far more meaningful than whether a country protects the motion of the spray of water behind a personal watercraft. ${ }^{53}$

As subjective aesthetic indicators, nontraditional marks do not fulfill any justifications for trademark protection. When a mark satisfies the justifications for trademark protection, it becomes appropriate to grant the trademark holder a right to exclude others from using the mark. ${ }^{54}$ It makes competitive sense to do this because we want and need companies to invest in trademarks to lower the transaction costs of purchasing goods and services. ${ }^{55}$ For example, the stronger the mark, the lower the search costs consumers incur when attempting to buy a product they like or want. ${ }^{56}$

However, nontraditional marks do not lower transaction costs. In fact, as they are subjective and indefinite, they actually increase transaction costs for the consumer. As such, they are inappropriate trademark subject matter as they do not further the purpose of trademark protection. They also waste scarce resources of the PTO. As nontraditional trademarks are a very rare breed, harmonizing to this standard is a curious development for a world where trademark laws and policies are so distinct. As the harmonization efforts that exist regarding nontraditional marks are only on a doctrinal level and not a theoretical level, the idea of trademark protection will remain disparate and distinct, even if some countries harmonize doctrine to allow for the protection of nontraditional trademarks.

\section{HISTORY OF THE WORDS "SYMBOL" AND "DEVICE"}

Today, nontraditional trademarks are deemed protectable as they constitute either a "symbol" or a "device" ${ }^{\text {"57 }}$ as used in the Lanham Act. ${ }^{58}$ To determine the

52. Alexis Weissberger, Note: Is Fame Alone Sufficient to Create Priority Rights: An International Perspective on the Viability of the Famous/Well-Known Marks Doctrine, 24 CARDOZO ARTS \& ENT. L.J. 739 (2006).

53. Personal Watercrafts (PWC) are very popular in the United States with approximately 20 million Americans riding them each year and annoyingly zipping around lakes and rivers, which are otherwise quiet and peaceful bodies of water. In 2005 there were 1.55 million PWCs in use throughout the country. PWC sales generate a considerable amount of revenue each year in the United States. In 2005, the industry grossed \$7.6 million in sales and sold more than 80,000 units. Personal Watercraft Industry Association, Personal Watercraft Sales, http://www.pwia.org/faq/sales.aspx (last visited October 1, 2009).

54. See William M. Landes \& Richard A. Posner, The Economics of Trademark Law, 78 TRADEMARK REP. 267, 270 (1988) (illustrating how trademarks are helpful for identification).

55. Id at 270-71. But see Barton Beebe, The Semiotic Analysis of Trademark Law, 51 UCLA L. REV. 621 (2004) (criticizing the economic analysis of trademark law).

56. Landes \& Posner, supra note 54 at 270-71; but see Beebe, supra note 55 (criticizing the economic analysis of trademark law).

57. Jerome Gilson \& Anne Gilson Lalonde, 1-2 GiLsON ON Trademarks $§ 2.11[1]$ (2010); Qualitex Co. v. Jacobson Prods. Co., 514 U.S. 159, 162 (1995) ("Since human beings might use as 
appropriateness of this determination, it is instructive to trace the history of the use of the words "symbol" and "device" as they have been used in the definition of trademarks over time. ${ }^{59}$ When viewed from a historical context, these words, as originally construed, did not support the notion of nontraditional trademarks.

Professor Lars Smith is correct when he claims that the use of the word "device" in the definition of trademarks was in the original Lanham Act; ${ }^{60}$ however, it did not start there. In fact, it appears that use of the words "symbol" and "device" as part of a definition of a trademark originally appeared in an English case from $1836 .{ }^{61}$ It is made confusing because "device" was not used in the definition of a trademark ${ }^{62}$ in any of the trademark legislation that preceded the Lanham Act and "symbol" was only used in the Act of $1920{ }^{63}$ Both the terms "symbol" and "device" are derived from a concept much older than the modern trademark laws.

The earliest known use of the words "symbol" and "device" to define a trademark occurred in the English case of Knott v. Morgan in $1836{ }^{64}$ In this case, the London Conveyance Company operated "omnibuses," horse drawn buslike vehicles, pictured below, in London. ${ }^{65}$ Morgan, the defendant, used the terms CONVEYANCE COMPANY and LONDON CONVEYANCE COMPANY on competing omnibuses. ${ }^{66}$ Morgan also used a green and gold star and garter type symbol, pictured below. ${ }^{67}$ The plaintiff had been using a similar symbol with similar coloring for some time prior to the defendant. ${ }^{68}$

a 'symbol' or 'device' almost anything at all that is capable of carrying meaning, this language, read literally, is not restrictive.").

58. 15 U.S.C. $\$ 1127(2006)$.

59. Professor Glynn Lunney has argued in multiple places that these words in the Lanham Act do not indicate Congressional support of the protection of trade dress. See Glynn S. Lunney, Jr., The Trade Dress Emperor's New Clothes: Why Trade Dress Does Not Belong on the Principal Register, 51 HASTINGS L.J. 1131 (2000) (arguing that trade dress is a judicial creation and not a legislative one); Glynn S. Lunney, Jr., Trademark Monopolies, 48 EMORY L.J. 367, 373-91 (1999). As nontraditional trademarks are another form of trade dress, presumptively, Lunney would agree that nontraditional trademarks, by definition, should not fall within the definition of a trademark under the Lanham Act.

60. Lars Smith, Trade Distinctiveness: Solving Scalia's Tertium Quid Trade Dress Conundrum, 2005 MiCH. ST. L. REV. 243, 247 (2005).

61. Knott v. Morgan, 48 Eng. Rep. 610 (1836); Francis H. Upton, A Treatise on the Law of TRADE MARKS 94-100 (1860) [hereinafter UPTON].

62. "Device" appeared in pre-Lanham Act legislation, however, "device" did not appear in any laws passed by Congress before the Lanham Act. See H.R. 2283, 77th Cong. (1942) (including the word "device") available at http://ipmall.info/hosted_resources/lipa/trademarks/ PreLanhamAct_019_HR_2283.pdf.

63. Act of $\mathrm{Mar}^{-} 19,1920$, available at http://ipmall.info/hosted_resources/lipa/ trademarks/PreLanhamAct_087_Act_of_1920.pdf.

64. Knott v. Morgan, 48 Eng. Rep. 610 (1836); UPToN, supra note 61.

65. Knott v. Morgan, 48 Eng. Rep. 610, 610-12 (1836); UPTON, supra note 61.

66. Id.

67. Id.

68. Id. 
The English court held that the plaintiff did not have exclusive rights in or to the words "London Conveyance Company" or "Conveyance Company," but it did deserve an injunction because of the defendant's use of these words in conjunction with the same or similar symbols. ${ }^{69}$ The defendant was enjoined using the same symbols and:

[F]rom running, or in any manner using or causing to be used, for the conveyance of psssengers [sic], his omnibus in the bill mentioned, or any other omnibus, having painted, stamped, printed, or written thereon the words or names "London Conveyance," or "Original Conveyance for Company," or any other names, words, or devices painted, stamped, printed, or written thereon, in such manner as to form or be a colourable imitation of the names, words and devices painted, stamped, printed, or written on the omnibuses of the Plaintiffs .... ${ }^{70}$

In this case, the word "device" and/or "symbol" does not relate to any nontraditional trademark. "1 In fact, the word "device" is used synonymously with the words "design mark." 72 That is, it merely identifies the colors and shapes of the star and garter type symbol as depicted below.
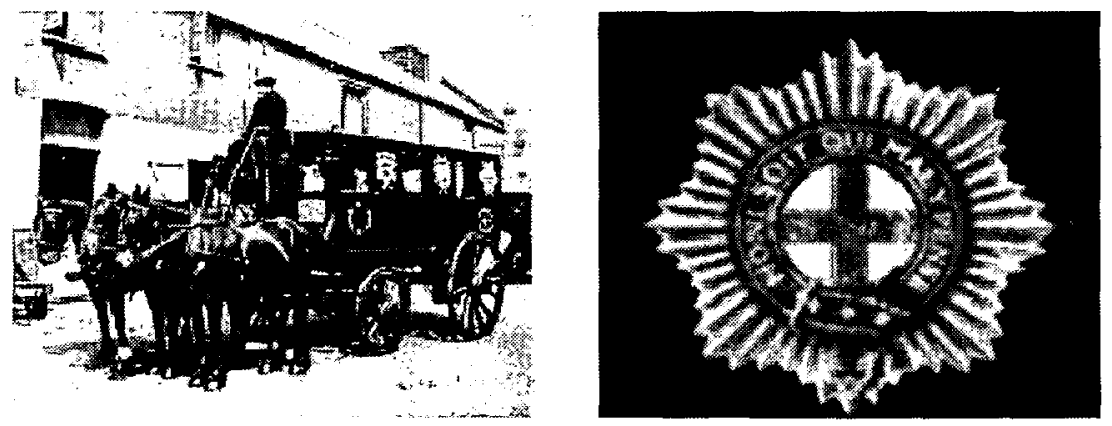

The first known case where the word "device" appears in the United States in a trademark case was in $1840 .{ }^{73}$ In Bell $v$. Locke, the court held that the DEMOCRATIC REPUBLICAN NEW ERA newspaper trademark was not infringed by NEW ERA newspaper. ${ }^{74}$ The court found that a distinguishing feature was the fact that the defendant used a large portrait of "a Bird of Jove"75 and the plaintiff used a rather modest picture of an eagle in conjunction with

69. Id. at 613 .

70. Id. at 613-14.

71. See Knott v. Morgan, 48 Eng. Rep. 610 (1836); UpToN, supra note 61 (using the words "device" and "symbol").

72. Id.

73. See Bell v. Locke, 8 Paige Ch. 75 (N.Y. Ch. 1840) (using the word "device").

74. Bell v. Locke, 8 Paige Ch. 75 (N.Y. Ch. 1840).

75. An eagle. 
their word marks. ${ }^{76}$ The court stated as follows: "But surely no one can mistake the wide-spread wings and the warlike attitude of 'the bird of Jove,' which occupies so large a space in the heading of the defendant's paper, for the very modest device which sustains the Democratic Republicanism of the complainant's New Era.",77

Clearly, in this case the word "device" was meant to indicate the plaintiff's design mark ${ }^{78}$ that consisted of an eagle that provided a distinguishing feature to the defendant's use of the word marks. The "device" spoken of, seems to be the relative eagles alone or the relative eagles in conjunction with the relative word marks. ${ }^{79}$ There was no mention of the word "symbol." "device" is synonymous here with "design mark," the words we would use today to describe such a trademark.

In 1844, the Circuit Court of Massachusetts characterized the packaging used to identify the plaintiff's thread as "devices." initial bill and found the following:

[T] he defendant has extensively manufactured and sold spurious threads of inferior quality, put up on spools similar to those used by complainants, and colored, stamped and labeled, and enclosed in envelopes resembling exactly the spools, labels, devices, trade marks and envelopes used by the complainants; that this conduct of the defendant has greatly injured the complainants, not only by depriving them of the profits on the sale of large quantities of their own threads, but by the prejudice to the reputation of the article manufactured by them, caused by the inferior quality of the threads sold by the defendant. $^{82}$

In this case, the use of the word "device" seems to mean the entire conglomeration of things that the plaintiff did to differentiate its goods from others. To be sure, the colors red and black were part of this device, but, just as assuredly, not as used separately from this overall source identifying device.

The next occurrence of the word "device" used in relationship to a trademark in the United States was in $1846 .{ }^{83}$ This time, the Chancery Court of New York refused to enjoin the defendant's use of a bee-hive and foliage mark on a match box because the plaintiff's mark was made slovenly and the defendant's "device"

76. Bell, 8 Paige $\mathrm{Ch}$. at 77 .

77. Id.

78. A design mark consists of graphics in place of or in addition to letters to identify source. See Boston Duck Tours, LP v. Super Duck Tours, LLC, 531 F.3d 1 (1st Cir. 2008) (involving duck graphics with the names of tour companies).

79. See Bell v. Locke, 8 Paige Ch. 75 (N.Y. Ch. 1840) (comparing the newspapers).

80. Id.

81. Taylor v. Carpenter, 3 Story 458, 23 F.Cas. 742 (1844).

82. Taylor v. Carpenter, 3 Story 458, 23 F.Cas. 742 (1844).

83. See Patridge v. Menck, 2 Sand. Ch. 622 (N.Y. Ch. 1846) (using the word "device"); UPTON, supra note 61, at 34-36. 
was made elegantly. ${ }^{84}$ In this case, as in all of the above cases regarding device, the court calls a "device" what a court or commentator today would call a "design mark." 85

The word "symbol" does not appear in the cases from 1836 until 1849. In the 1849 case, Amoskeag Mfg. Co. v. Spear, ${ }^{86}$ the court clearly claims that the definition of trademarks should extend to "symbols" as follows:

Every manufacturer and every merchant for whom goods are manufactured, has an unquestionable right to distinguish the goods that he manufactures or sells, by a peculiar mark or device, in order that they may be known as his in the market for which he intends them, and that he may thus secure the profits that their superior repute as his, may be the means of gaining.

The owner of an original trade mark, has an undoubted right to be protected in the exclusive use of all the marks, forms or symbols that were appropriated as designating the true origin or ownership of the article or fabric to which they were affixed; but he has no right to an exclusive use of any words, letters, figures or symbols, which have no relation to the origin or ownership of the goods, but are only meant to indicate their name or quality. He has no right to appropriate a sign or symbol which, from the nature of the fact which it is used to signify, others may employ with equal truth, and therefore have an equal right to employ, for the same purpose.

In 1853 the Supreme Court of New York that the definition of trademark would include both the word "symbol" and "device:"88

The principle is well settled that a manufacturer may, by priority of appropriation of names, letters, marks, or symbols of any kind, to distinguish his manufactures, acquire a property therein, as a trade mark, for the invasion of which an action for damages will lie; and in the exclusive use of which he may have protection, when necessary, by injunction. . . . In all cases where names, signs, marks, brands, labels, words or devices of any kind can be advantageously used to designate the goods or property, or particular place of business, of a person engaged in trade or manufacture, or any similar business, he may adopt and use such as he pleases, which are adapted to that end and have not been before appropriated; and no other person can lawfully imitate

84. Patridge v. Menck, 2 Sand. Ch. 622 (N.Y. Ch. 1846); UpToN, supra note 61, at 34-36.

85. See Patridge v. Menck, 2 Sand. Ch. 622 (N.Y. Ch. 1846) (using the word "device" to describe the image on a matchbox).

86. Amoskeag Mfg. Co. v. Spear, 2 Sand. NY 599 (1849); UPTON, supra note 61, at 85-126.

87. Id. at 605-06; UPTON, supra note 61, at 86.

88. Stokes v. Landgraff, 17 Barb. 608 (N.Y. Sup. Ct. 1853); UPTON, supra note 61, at 87. 
them, and by that means sell his own goods or property, or carry on his business, as the goods, property or business of the former.

By 1860 , Francis $\mathrm{H}$. Upton, the primary trademark commentator of the day, reported that the definition of trademark included both the words "device" and "symbol." "A trade mark is the name, symbol, figure, letter, form or device, adopted and used, by a manufacturer, or merchant, in order to designate the goods that he manufactures, or sells ....,"91

In 1877, the U.S. Supreme Court gave trademarks the expansive definition that is very similar to the definition used by courts today. ${ }^{92}$ In McLean $v$. Fleming, the Court defined a trademark as "a name, symbol, figure, letter, form, or device....".93

Subsequently, in 1878 , another trademark commentator of the time, Charles E. Coddington, defined the trademark in the following terms: "A trademark is a name, symbol, figure, letter, form or device, adopted and used by a manufacturer or merchant to designate the goods he manufactures or sells and to distinguish them from the goods of another." ${ }^{94}$

One of the earliest reported alleged nontraditional trademark case where "device" was used to describe the trademark was A. Leschen \& Sons Rope Co. v. Broderick \& Bascom Rope Co. ${ }^{95}$ In this case, a red stripe was placed on wire rope $^{96}$ It was this colored strand that was claimed to be the plaintiff's trademark. ${ }^{97}$ The United States Supreme Court held that color alone was too indefinite to constitute a trademark. ${ }^{98}$ The court called the colored strand imprecisely defined and "manifestly too broad." 99

In Coca-Cola Co. v. Koke Co. of America, in referring to trademarks as a "device," the court held that "[t]he product including the coloring matter is free to all who can make it if no extrinsic deceiving element is present."100 Although

89. Id.

90. UPTON, supra note 61 , at 9.

91. UPTON, supra note 61 , at 9.

92. See McLean v. Fleming, 96 U.S. 245, 254 (1877) (describing a trademark as "a name, symbol, figure, letter, form, or device").

93. McLeav v. Fleming, 96 U.S. 245, 254 (1877) (citing UPTON, supra note 61 as controlling authority).

94. Charles E. Coddington, A Digest of The Law of Trademarks $\S 22$ (1878). As support for this proposition, the author relies on the following cases: (1869) Phila. Ct. of Com. Pleas., Ferguson v. Davol Mills, 7 Phila. 253; S. C., 2 Brewster 314. However, these cases could not be located and appear lost.

95. See A. Leschen \& Sons Rope Co. v. Broderick \& Bascom Rope Co., 201 U.S. 166 (1906) (using the word "device").

96. A. Leschen \& Sons Rope Co. v. Broderick \& Bascom Rope Co., 201 U.S. 166, 170 (1906).

97. Id. at 170

98. Id. at 170 . "Whether mere color can constitute a valid trade-mark may admit of doubt." Id. at 171 .

99. Id. at 171.

100. Coca-Cola Co. v. Koke Co. of Am., 254 U.S. 143, 147 (1920). 
the mark COCA-COLA has secondary meaning, it did not give the plaintiff a right to prevent the use of "dope" as used on a brown, bubbly beverage.

All of this significant use of the words "device" and "symbol" to define a trademark did not motivate the drafters of the Trademark Acts of $1870,{ }^{102}$ $1876,{ }^{103} 1881,{ }^{104} 1882,{ }^{105} 1905,{ }^{106}$ or $1920^{107}$ to include the word "device" in defining a trademark and only the Trademark Act of $1920^{108}$ used the word "symbol." Therefore, when the Lanham Act takes up the yoke of "symbol" and "device" 109 it had some common law history on which to rely; however, that history actually teaches away from the current broad understanding of these words. ${ }^{110}$ Most importantly, in 1988 Congress expressly "expanded" definition of a trademark and retained "symbol or device" "so as not to preclude the registration of colors, shapes, sounds or configurations where they function as trademarks." $" 112$

The problem, of course, was that "symbol" and "device" had almost exclusively meant design marks, not nontraditional trademarks. ${ }^{113}$ In the only case where it seems to have been used to define color strips as used on rope, the Court rejected that claim as too broad. ${ }^{114}$ Then, in 1995, when the Supreme Court relied on this very language to claim that color alone is appropriate subject

101. Id. at 147 .

102. Trade--Mark Act of 1870 , available at http://ipmall.info/hosted_resources/lipa/ trademarks/PreLanhamAct_082_Act_of_1870.pdf.

103. Trade--Mark Act of Aug. $\overline{4}, \overline{1} 876$, available at http://ipmall.info/hosted_resources/lipa/ trademarks/PreLanhamAct_083_Act_of_1876.pdf.

104. Trade--Mark Act of Mar. 3,1881 , available at http://ipmall.info/hosted_resources/lipa/ trademarks/PreLanhamAct_084_Act of 1881.pdf.

105. Trade--Mark Act of Aug. $\overline{5}, 1882$, available at http://ipmall.info/hosted_resources/lipa/ trademarks/PreLanhamAct_085_Act_of_1882.pdf.

106. Trade--Mark Act of Feb. ${ }^{-} 20,1905,15$ U.S.C. $\$ \S 81-108$, available at http:/ipmall.info/hosted_resources/lipa/trademarks/PreLanhamAct_086_Act_of_1905.pdf.

107. Trade--Mark Act of 1920, available at http://ipmall.info/hosted_resources/ lipa/trademarks/PreLanhamAct_087_Act_of_1920.pdf.

108. Id.

109. 15 U.S.C. $\S 1127$ (2006) ("The term 'trademark' includes any word, name, symbol, or device ....").

110. See supra Part III.

111. In a Senate Report accompanying the Trademark Law Revision Act of 1988 Congress expressed its intent to broaden the definition of "trademark" and retain "symbol and device" to encompass nontraditional trademarks such as color, sound, etc. S. REP. No. 100-515, at 44 (1988).

112. Id. See also The United States Trademark Association Trademark Review Commission Report and Recommendations to USTA President and Board of Directors, 77 TRADEMARK REP. 375, 421 (Sept.-Oct. 1987) (expressing intent to allow registration of things "such things as a color, shape, smell, sound, or configuration which functions as a mark"); Moon-Ki Chai, Note, Protection of Fragrances Under the Post-Sale Confusion Doctrine, 80 TrADEMARK REP. 368, 371-72 (JulyAug. 1990) ("The Committee 'determined that the terms 'symbol, or device' should not be deleted or narrowed to preclude registration of such things as color, shape, smell, sound, or configuration which functions as a mark.").

113. See supra Part III.

114. See A. Leschen \& Sons Rope Co. v. Broderick \& Bascom Rope Co., 201 U.S. 166 (1906) (rejecting claim). 
matter for a trademark, it is not difficult to see how people might conclude that this was a "stunning breakthrough" for nontraditional trademarks. ${ }^{115}$

Little in the etymological history of the words "symbol" and "device" hints at the expansive meaning now ascribed to those terms. ${ }^{16}$ In historical terms, these words have changed from meaning a design mark to now meaning the vertical motion of a car door opening or the vertical spray of water from the back of a personal water craft. ${ }^{117}$ As Congress expressly admitted in 1988, this is an "expansion" of what heretofore had been the trademark right. ${ }^{118}$ As Gilson says, this is "stunning." 119 In context, this expansion is not explained or warranted. As persuasive plaintiff attorneys gradually made their cases, the expansion occurred. This expansion can be ascribed to the persuasive powers of the common law lawyer, not to any particular legislative enactment. In this context, we can see that the Qualitex ${ }^{120}$ case was a radical departure from the 150 years of common law case history that preceded it. ${ }^{121}$

\section{COLOR}

The issue of registering nontraditional marks received a major incentive when the Supreme Court held that there was no per se rule against color alone being granted trademark status. ${ }^{122}$ In Qualitex v. Jacobson, the Supreme Court flippantly dismissed objections to color alone being a trademark that had stood for decades. ${ }^{123}$

In Qualitex, the Supreme Court determined that the previous belief that there was a "per se" rule against granting trademark protection for color alone was in error. ${ }^{124}$ In Qualitex, Justice Bryer's opinion squarely addresses whether or not a color alone may be suitable trademark subject matter. ${ }^{125}$ Justice Breyer concluded that because the Lanham Act says "any word, name, symbol, or device" may be a valid trademark, as long as it acts to identify source, color alone may also play the role of a valid trademark. ${ }^{126}$

Although taken for granted now in the United States and sometimes misstated, ${ }^{127}$ the United States remains the only jurisdiction in the world to so

115. See Gilson \& LaLonde, supra note 4.

116. See supra Part III.

117. See supra notes $26-27$.

118. See supra note 111.

119. See Gilson \& LaLonde, supra note 4.

120. Qualitex Co. v. Jacobson Prods. Co., Inc., 514 U.S. 159 (1995).

121. See supra Part III.

122. See Qualitex, 514 U.S. 159.

123. Id. See infra Part XIII.

124. Qualitex Co. v. Jacobson Prods. Co., Inc., 514 U.S. 159, 161-62 (1995).

125. Id.

126. Qualitex Co. v. Jacobson Prods. Co., Inc., 514 U.S. 159, 162 (1995).

127. See Glenda Labadie-Jackson, Through the Looking Hole of the Multi-Sensory Trademark Rainbow: Trademark Protection of Color Per Se Across Jurisdictions: The United States, Spain and the European Union, 7 RICH. J. GLOBAL L. \& BUS. 91, 92 (2008) (omitting the word "device" 
broadly recognize rights in color alone. ${ }^{128}$ The European Union, the World Intellectual Property Organization and the Madrid Protocol ${ }^{129}$ all arguably allow for and make specific provisions for the registration of color alone as a trademark, however, judicial support in that context is sparse. ${ }^{130}$

In the United States, registration of color alone is justified by categorizing it as a "device" under the Lanham Act. ${ }^{131}$ This was contemplated when the Lanham Act was amended in $1988 .{ }^{132}$ That is, because the statutory definition of a trademark now includes the terms "symbol or device," and this no longer means "design mark," the possibility of registering things, such as color, that are not traditional word marks is supported by the statute itself. ${ }^{133}$

This result has been harshly criticized by commentators. Perhaps the most persuasive and direct attack came recently from Ann Bartow. ${ }^{134}$ Professor Bartow argued that color alone should not be recognized as a trademark. ${ }^{135}$ To do so, she argues, allows companies to monopolize the aesthetic and communicative attributes of color. ${ }^{136}$ Given that color is also inherently functional and the consequent uncertainties created by protecting color, Professor Bartow would never allow color alone to act as a trademark. ${ }^{137}$

Professor Bartow seems correct. Protecting color per se seems to extend the trademark beyond where it is needed to encourage use by corporations to reduce transaction costs. More importantly, though, color alone is not a frequently

from the quoted section of the Lanham Act).

128. See supra notes 126-27.

129. Labadie-Jackson, supra note 127 at 101-06; Jaume Pellise Capell \& Maria Teresa Solanelles Battle, La Proteccion del Color Unico como Marca en el Derecho Comunitario, REVISTA DE DERECHO MERCANTIL 1101,1123-1124 (1998).

130. See, e.g., Libertel Groep BV v. Benelux-Merkenbureau, Case C-104/01 (Eur. Ct. Justice May 6, 2003), available at_http://curia.europa.eu/jcms/jcms/j_6/ (search for Case no. "C-104/01") (rejecting validity of color trademark).

131. 15 U.S.C. $\S 1127$ (2006).

132. Trademark Law Revision Act of 1988, Pub. L. No. 100-667, 134, 102 Stat. 3935, 3947 (1988) (current version at 15 U.S.C. $\$ 1127$ (2006)); S. REP. No. 100-515 at 44 (1988), reprinted in 1988 U.S.C.C.A.N. 5577, 5607 ("The revised definition intentionally retains . . . (iv) the words 'symbol or device' so as not to preclude the registration of colors, shapes, sounds or configurations where they function as trademarks.") See also, Glynn S. Lunney, The Trade Dress Emperor's New Clothes: Why Trade Dress Does Not Belong On The Principal Register, 51 Hastings L.J. 1131, 1191-92 (2000) ("Rather than choosing an affirmative statement ('so as to include') that would suggest that Congress intended to resolve the issue, the Senate Report chose a negative phrasing ('so as not to preclude'). This choice suggests that Congress was neither foreclosing nor requiring the registration of such material.".2.

133. For the argument that "force-fitting" trade dress into the word "device" is inappropriate, see id.

134. Ann Bartow, The True Colors of Trademark Law: Greenlighting a Red Tide of Anti Competition Blues, 97 KY. L.J. 263 (2009).

135. Id.

136. Id. at $289-90$.

137. Id. 
litigated subject matter, even though the Court in Qualitex seemed to believe it was worthy of Supreme Court attention. ${ }^{138}$

Virtually all of the reported cases regarding nontraditional trademarks are litigation over color. ${ }^{139}$ Of the total reported cases since 1947 , less than $1 \%$ of the total claim color alone as a trademark; ${ }^{140}$ however, of the 35 nontraditional trademark cases reported $30(86 \%)$ of them are about color. ${ }^{141}$ Although there are 345 trademark applications for color alone ( $44 \%$ of the total), 152 of these marks (nearly $45 \%$ ) were either abandoned before they reached registration or were cancelled for nonuse once registered. ${ }^{142}$ It takes on average 37 months to obtain a registration for a color mark. ${ }^{143}$ Therefore, it appears that commentators and courts alike exaggerate the significance of this nontraditional trademark.

Arguably, color may be the least subjective of the nontraditional trademarks. Using the Pantone Matching System, a color-coding system, subjectivity may by lessened. ${ }^{144}$ This coding system gives every shade of every color a number. ${ }^{145}$

138. Qualitex Co. v. Jacobson Prods. Co., Inc., 514 U.S. 159 (1995).

139. See Mitchell Study on Trademark Litigation, http://www.wmitchell.edu/intellectualproperty/?page $=321 \&$ Mitchell + Study+on+Trademark+Litigation (compiling and organizing reported trademark cases).

140. See DAP Prods., Inc. v. Color Tile Mfg., Inc., 821 F. Supp. 488 (S.D. Ohio 1993); Ideal Toy Corp. v. Chinese Arts \& Crafts, Inc., 530 F. Supp. 375 (S.D.N.Y. 1981); Pennwalt Corp. v. Zenith Labs., Inc., 472 F. Supp. 413 (E.D. Mich. 1979); Smithkline Beckman Corp. v. Pennex Prods. Co., 605 F. Supp. 746 (E.D. Pa. 1985); Transp., Inc. v. Mayflower Servs., Inc., 769 F.2d 952 (4th Cir. 1985); Am. Basketball Ass'n v. AMF Voit, Inc., 358 F. Supp. 981 (S.D.N.Y. 1973); Barnes Group, Inc. v. Connell Ltd. P'ship, 793 F. Supp. 1277 (D. Del. 1992); Emba Mink Breeders Ass'n v. United Mink Producers Ass'n, 224 F. Supp. 228 (W.D. Wis. 1963); Inwood Labs., Inc. v. Ives Labs., Inc., 456 U.S. 844 (1982); Ives Labs., Inc. v. Darby Drug Co., 488 F. Supp. 394 (E.D.N.Y. 1980); Plastilite Corp. v. Airlite Plastics Co., 390 F. Supp. 1141 (D. Neb. 1975); Schmidt Mfg. Co. of S.C. v. Sherrill Indus., Inc., 249 F. Supp. 480 (W.D.N.C. 1965); Sylvania Elec. Prods., Inc. v. Dura Elec. Lamp Co., 247 F.2d 730 (3d Cir. 1957); Union Carbide Corp. v. Fred Meyer, Inc., 619 F. Supp. 1028 (D. Or. 1985); Ventura Travelware, Inc. v. Baltimore Luggage Co., 322 N.Y.S.2d 93 (N.Y. Sup. Ct. 1971); W.H. Brady Co. v. Lem Prods., Inc., 659 F. Supp. 1355 (N.D. Ill. 1987); Anheuser-Busch, Inc. v. Customer Co., 947 F. Supp. 422 (N.D. Cal. 1996); Black \& Decker (U.S.), Inc. v. Pro-Tech Power, Inc., 26 F. Supp. 2d 834 (E.D. Va. 1998); Bd. of Supervisors of La. State Univ. v. Smack Apparel Co., 438 F. Supp. 2d 653 (E.D. La. 2006); Keystone Consol. Indus. Inc. v. Midstates Distrib. Co., 235 F. Supp. 2d 901 (C.D. Ill. 2002); Pearson Indus., Inc. v. Pet Friendly, Inc., 33 F. Supp. 2d 1322 (M.D. Ala. 1999); Qualitex Co. v. Jacobson Prods. Co., 514 U.S. 159 (1995); Unique Sports Prods., Inc. v. Babolat VS, 403 F. Supp. 2d 1229 (N.D. Ga. 2005); Am. Cyanamid Co. v. Nutraceutical Corp., 54 F. Supp. 2d 379 (D.N.J. 1999); Baughman Tile Co. v. Plastic Tubing, Inc., 211 F. Supp. 2d 720 (E.D.N.C. 2002); Deere \& Co. v. MTD Holdings, Inc., No. 00 Civ 5936 (LMM), 2004 U.S. Dist. LEXIS 2550 (S.D.N.Y. Feb. 18, 2004); Libman Co. v. Vining Indus., Inc., 69 F.3d 1360 (7th Cir. 1995); Rainbow Play Sys., Inc. v. GroundScape Techs., LLC, 364 F. Supp. 2d 1026 (D. Minn. 2005); Shakespeare Co. v. Silstar Corp. of Am., 110 F.3d 234 (4th Cir. 1997); Master Distribs., Inc. v. Pako Corp., 777 F. Supp. 744 (D. Minn. 1991) (each involving disputes over color as a trademark).

141. Id.

142. See infra app. C.

143. See infra app. D.

144. See generally Pantone, http://www.pantone.com (associating identifying numbers with a range of colors).

145. Id. 
The Pantone Matching System is an internationally recognized color-coding system. ${ }^{146}$ Pantone Corporation lists over 1000 colors and it has assigned each color a number code. ${ }^{147}$ This allows Pantone to match colors uniformly worldwide. ${ }^{148}$ Therefore, one might claim Pantone Matching System 300, which is a blue color. However, for Thrifty, Inc., claiming this number was not enough to overcome an Examiner's rejection based on a claim that the Applicant failed to provide an adequate description of the mark. ${ }^{149}$

However, even if the subjectivity of color marks is lessened with the Pantone Matching System, its use in American trademark law would be limited. Context is an important factor considering whether a mark is infringed. That is, courts will not tolerate taking a mark out of context and, for example, doing a side-byside comparison to determine if the two marks are confusingly similar. ${ }^{150}$ Therefore, although it is, of course possible to run two different colors through a spectrograph to determine similarity, no court would admit that into evidence. To determine similarity, the mark must be viewed as consumers confront the mark in the marketplace. ${ }^{151}$ Consumers do not look at the color of a product through a spectrograph before making a purchase; therefore, it would not be admissible.

\section{SOUND}

There have been 336 applications for sound before the PTO. ${ }^{152}$ This amounts to over $43 \%$ of all nontraditional trademarks. ${ }^{153}$ Sound and color (44\%) make up $87 \%$ of all nontraditional trademarks. ${ }^{154}$ Four of the 35 reported cases $(11 \%)$ are sound marks and the plaintiff has prevailed only once. ${ }^{155}$

The PTO apparently thinks rather lightly of sound marks as the only list of these marks appears in the "Kids" section of the PTO web site which also includes things like games, puzzles other links, and the most peculiar looking swashbuckling Pac Man-like character yielding a wooden sword labeled "stop

146. Id.

147. Id.

148. Id.

149. In re Thrifty, 274 F.3d 1349 (Fed. Cir. 2001) (sustaining rejection where applicant's claimed color blue on a wall was materially altered when applied to several other objects).

150. V Secret Catalogue, Inc. v. Moseley, 54 U.S.P.Q.2d 1092, 1095 (W.D. Ky. 2000).

151. Levi Strauss \& Co. v. Blue Bell, Inc., 632 F.2d 817, 821-22 (9th Cir. 1980).

152. See infra app.A.

153. See infra app. A.

154. See infira app. A.

155. See Louis Rich, Inc. v. Horace W. Longacre, Inc., 423 F. Supp. 1327 (E.D. Pa. 1976) (enjoining defendant "from using term 'gobble-gobble' in the advertising of any processed turkey product ... ."); Booth v. Colgate-Palmolive Co., 362 F. Supp. 343 (S.D.N.Y. 1973) (granting defendant's motion to dismiss); Am. Family Life Ins. Co. v. Hagan, 266 F. Supp. 2d 682 (N.D. Ohio 2002) (denying plaintiff's motion for injunctive relief); G.M.L., Inc. v. Mayhew, 188 F. Supp. 2d 891 (M.D. Tenn. 2002) (dismissing plaintiff's claims). 
piracy." 156 The peculiar part is that the character appears to be attractive to a child interested in pirates, but the content of that portion of the site is clearly intended for someone well educated in the art of knock-off goods. ${ }^{157}$

Figure 1: PTO's Graphic User Interface for Children of "Pirated" Marks"

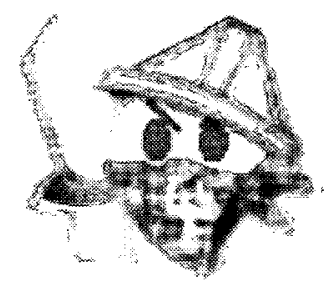

It certainly appears that the registrants or applicants do not take these applications as lightly as the PTO does. Reviewing the application records using the TARR (Trademark Applications and Registrations Retrieval) database of the PTO discloses the fact that applicants for sound marks do not have an easy time obtaining registrations. ${ }^{159}$ It takes an average of just under 24 months to obtain a trademark registration after application. ${ }^{160}$ The average pendency for all marks is 13.9 months. ${ }^{161}$ These applications are often refused for being functional or for failing to function as a trademark that can be used to identify and distinguish applicant's goods from others and to identify source. ${ }^{162}$ That is, it takes significantly more time and therefore costs significantly more to obtain a registration for a sound mark rather than a traditional mark.

Perhaps the most famous case involving a claimed sound as a trademark occurred in 1994 when Harley Davidson filed a trademark application for the sound of its motorcycle idling. ${ }^{163}$ In the application, Harley Davidson described this sound as saying the word "potato", slowly, over and over. ${ }^{164}$ Harley

156. United States Patent and Trademark Office, Kids Pages, http://www.uspto.gov/go/kids/

157. United States Patent and Trademark Office, Kids - Stop Piracy, http://www.uspto.gov/web/offices/ac/ahrpa/opa/kids/kidantipiracy.htm

158. Whoever in the PTO dreamed up this graphic certainly doesn't have kids.

159. See infra app. B.

160. See infra app. D.

161. In 2008 it took an average of 13.9 months to get a traditional mark from application to registration. United States Patent and Trademark Office, Table 15: Summary of Trademark Examining Activities, http://www.uspto.gov/web/offices/com/annual/2008/oai_05_wlt_15.html.

162. Michael B. Sapherstein, The Trademark Registerability of the Harley-Davidson Roar: A Multimedia Analysis, 1998 B.C. INTELL. PROP. \& TECH. F. 101101 (1998) available at http://www.bc.edu/bc_org/avp/law/st_org/iptf/articles/content/1998101101.html.

163. Harley-Davidson, Inc., U.S. Patent Serial No. 74,485,223 (filed Feb. 1, 1994) ("The mark consists of the exhaust sound of applicant's motorcycles, produced by V-Twin, common crankpin motorcycle engines when the goods are in use.").

164. Id. See also Jodie Dejonge, Harley Seeks Protection for its 'Spudly' Sound: Distinctive Motorcycle Engine Revs Up Trademark Concerns, The Seattle Times, March 28, 1996, available at http://community.seattletimes.nwsource.com/archive/?date=19960328\&slug=2321321 (Harley 
Davidson applied for this mark in 1994, it was allowed by the PTO in 1995 and five years later in 2000 it was expressly abandoned by Harley Davidson after several parties, including Suzuki, Honda, Kawasaki and Polaris, filed oppositions $^{165}$ and three months before the TTAB sustained those oppositions. ${ }^{166}$

One of the first sound trademarks to be registered in the United States was filed in 1970 by NBC Universal, Inc. for the now famous "NBC chimes." The identification of goods for this registration reads as follows:

\section{THE MARK COMPRISES A SEQUENCE OF CHIME-LIKE MUSICAL NOTES WHICH ARE IN THE KEY OF C AND SOUND THE NOTES G, E, C, THE "G" BEING THE ONE JUST BELOW MIDDLE C, THE "E" THE ONE JUST ABOVE MIDDLE C, AND THE "C" BEING MIDDLE C, THEREBY TO IDENTIFY APPLICANT'S BROADCASTING SERVICE. ${ }^{168}$}

Of course, some sound marks have attained an iconic reputation. Everyone knows the roar of the MGM lion, ${ }^{169}$ first used in $1924,{ }^{170}$ and the Harlem Globetrotters whistling the song Sweet Georgia Brown, ${ }^{171}$ first used in $1948 .{ }^{172}$ However, few people would recognize "'Hisamitsu' sung over the sound of four musical tones, E, A, E, and F sharp. The first three notes being eighth notes and the final note being a tied eighth and half note," for medicated transdermal patches ${ }^{173}$ or the loon call of the Minnesota State Lottery. ${ }^{174}$ That is, few have become iconic, like the Menards song about how we can all "Save Big Money at Menards." $" 175$ Most of the trademark applications or registrations for sound marks went the way of Anheuser-Busch's howling wolf. ${ }^{176}$ In fact, of the 336

Davidson's attorney giving the verbal description of that mark as a very fast "potato-potatopotato"); Nick Pisarsky, NOTE: PoTAYto-PoTAHto-Let's Call the Whole Thing Off: Trademark Protection of Product Sounds, 40 CONN. L. REv. 797, 806 (2008) (discussing the Harley-Davidson sound mark).

165. See supra note 163.

166. For a chronology, see United States Patent and Trademark Office, Trademark Trial and Appeal Board Inquiry System, http://ttabvue.uspto.gov/ttabvue/v?pnam=NOSTALGIA\% 20MOTORCYCLE\%20CO.,\%20INC.\%20\%20 (including dates and prosecution history).

167. NBC Universal, Inc., Reg. No. 916,522, available at http://tarr.uspto.gov/servlet/tarr? regser=serial\&entry $=72349496 \&$ action $=$ Request + Status.

168. Id.

169. Metro-Goldwyn-Mayer Lion Corp., Reg. No. 1,395,550, available at http://tarr.uspto.gov/servlet/tarr?regser=serial\&entry=73553567\&action=Request+Status.

170. Id.

171. Harlem Globetrotters International, Inc., Reg. No. 1,700,895 available athttp://tarr.uspto.gov/servlet/tarr?regser=serial\&entry=74158626\&action=Request+Status.

172. Id.

173. Hisamitsu Pharmaceutical Co., Inc., Reg. No. 2,814,082 available at http://tarr.uspto.gov/servlet/tarr?regser=serial\&entry=78101339\&action=Request + Status.

174. Minnesota State Lottery Agency, Reg. No. 2,600,195, available at http://tarr.uspto.gov/servlet/tarr?regser=serial\&entry=7607721 1\&action=Request+Status.

175. Menard, Inc., Reg. No. 2,723,532, available at http://tarr.uspto.gov/servlet/tarr? regser=serial\&entry $=76368849 \&$ action $=$ Request + Status.

176. Anheuser-Busch, Inc., Reg. No. 2,207,874, available at http://tarr.uspto.gov/servlet/tarr? 
sound mark applications in the 62-year history of the Lanham Act, 28 were cancelled for nonuse of the registered mark and 112 were abandoned before they reached the registration stage. ${ }^{177}$

Sound marks constitute $43 \%$ of all nontraditional mark applications, yet 140 of the initial 336 applications didn't survive to registration or were cancelled thereafter. ${ }^{178}$ Very few would be deemed "famous" under the Dilution Act. ${ }^{179}$

\section{SCENT}

The most popular case where the scent of a product was recognized as a trademark was In re Clarke. ${ }^{180}$ In this case, Celia Clarke, doing business as Clarke's OSEWEZ, produced a yarn that smelled like plumeria flowers. ${ }^{181}$ The Trademark Trial and Appeal Board found the scent to be distinctive of the yarn, possessed secondary meaning and, therefore, upheld Mrs. Clarke's application to register the mark as used on kits where the purchaser would knit a skunk that smelled like plumeria. ${ }^{182}$

Perhaps no American has played a larger role in getting scents recognized as trademarks than James E. Hawes. Hawes first advocated for the registration of scent trademarks in $1989 .{ }^{183}$ Hawes represented Cecilia Clarke in her petition before the TTAB to register the scent of her yarn in $1990 .{ }^{184}$ Unfortunately for Hawes, on September 29, 1997, Clarke's registered trademark for the plumeria scented thread was canceled by the PTO for a failure to file a Continuing Use Affidavit under Section 8 of the Lanham Act. ${ }^{185}$ That is, the mark was cancelled for nonuse.

It appears that the registration for the scent of Clarke's yarn was more significant for Hawes than it was for Clarke. Although this case is depicted by some as a major breakthrough that others ought to follow, ${ }^{186}$ very few applicants have, in fact, obtained trademark registrations for scents and in other places this

\footnotetext{
regser=serial\&entry $=75086922$ \&action $=$ Request + Status.

177. See infra app. C.

178. See infra app. C.

179. See David S. Welkowitz, Trademark Dilution: Federal State, and International LAW 177 (2002); 15 U.S.C. $\$ 1125$ (c) (fame is ephemeral in nature and difficult to identify, which is why Congress laid out multiple factors including "(i) The duration, extent, and geographic reach of advertising and publicity of the mark, whether advertised or publicized by the owner or third parties. (ii) The amount, volume, and geographic extent of sales of goods or services offered under the mark. (iii) The extent of actual recognition of the mark. (iv) Whether the mark was registered under the Act of March 3, 1881, or the Act of February 20, 1905, or on the principal register.")

180. In re Clarke, 17 U.S.P.Q.2d (BNA) 1238 (T.T.A.B. 1990).

181. Id.

182. Id.

183. James E. Hawes, Fragrances as Trademark, 79 TRADEMARK REP. 134 (1989).

184. In re Clarke, 17 U.S.P.Q.2d (BNA) 1238 (T.T.A.B. 1990).

185. Celia Clarke, Reg. No. 1,639,128, available at http:/tarr.uspto.gov/servlet/ tarr?regser=serial\&entry $=73758429$.

186. Faye M. Hammersley, Comment, The Smell of Success: Trade Dress Protection for Scent Marks, 2 MARQ. INTELL. PROP. L. REv. 105 (1998).
} 
idea has been harshly criticized. ${ }^{187}$ In fact, there are currently only 12 registered trademarks for scents in the United States and only 28 applications. ${ }^{188}$ Nine of the 28 applications have either been abandoned or subsequently cancelled for nonuse. ${ }^{189}$ It takes an average of 26 months to obtain a registration. ${ }^{190}$ There are no reported cases where a scent trademark was at issue.

In fact, lessons from osphresiology, the science of smells, teach us that scents are inappropriate for trademark protection. The actual scent that one recognizes is affected by temperature and humidity. ${ }^{191}$ Therefore, not only is the scent that is projected from an article different according to these and other variables, the receiver also does not sense the same scent from time to time. ${ }^{192}$ Human beings have an enormous capacity to remember sounds and sights. The human brain can only remember sixteen smells for a long period of time. ${ }^{193}$ Also, science has not determined the role that, for example, simple cold remedies such as Zicam can play in impairing one's sense of smell. ${ }^{194}$

Few scent marks are registered in European Union. ${ }^{195}$ The "smell of fresh cut grass," for example, has been issued for use on tennis balls. ${ }^{196}$

Therefore, because scents are perceived differently over time and because each person's subjective olfactory sense differs based, for example, on whether one has a cold or not, ${ }^{197}$ scent trademarks do not possess the incident of consistency that is required to make a scent worthy of trademark protection.

\section{TASTE}

To date, there have been nine trademark applications in the United States for taste. ${ }^{198}$ Thus far, no registrations have been issued ${ }^{199}$ and all nine applications

187. Douglas D. Churovich, Intellectual Property: Policy Considerations From A Practitioner's Perspective: Scents, Sense or Cents?; Something Stinks in the Lanham Act Scientific Obstacles to Scent Marks, 20 ST. LoUIS U. PUB. L. ReV. 293 (2001).

188. See infra app. A.

189. See infra app. C.

190. See infra app. D.

191. Churovich, supra note 187 , at 301 .

192. Churovich, supra note 187 , at 302.

193. Churovich, supra note 187 , at 302.

194. See Saundra Young, FDA Warns Against Using 3 Popular Zicam Cold Meds, CNN Online, June 16, 2009, http://www.cnn.com/2009/HEALTH/06/16/zicam.fda.warning/index.html (reporting on the drug's potential threat to cause loss of sense of smell).

195. See Katerina Shaw, Likelihood of Coexistence: A Comparative Analysis of the Interplay Between European Trademark Law and Free Competition, 18 U. BALT. INTELL. Prop. L.J. 51, 69 (2009) (discussing EU's reluctance to grant trademark protection to a scent).

196. Vennootschap onder Firma Senta Aromatic Marketing, Trade mark No. 428870, available at http://oami.europa.eu/CTMOnline/RequestManager (search for Trade mark No. 428870); Case No. R 156/1998-2, Vennootschap onder Firma Senta Aromatic Marketing, [1999] E.T.M.R. 429 (Eur. Comm. Trade Marks Office, 2d Board of Appeal Feb. 11, 1999) available at http://oami.europa.eu/legaldocs/boa/1998/EN/R0156_1998-2.pdf.

197. Churovich, supra note 187, at 303-04.

198. See infra app. A.

199. See infra app. A. 
have been abandoned. ${ }^{200}$ Although a flavor may be a "device" under the Lanham Act and therefore not statutorily barred, no one has convinced a court or the PTO that a flavor deserves trademark protection. ${ }^{201}$ The best case for flavor trademarks apparently is in the pharmaceutical industry. ${ }^{202}$

In a very closely watched case by flavor lovers, N.V. Organon, a Dutch company, failed to convince the TTAB that its flavor orange deserved trademark protection on antidepressant medication. ${ }^{203}$

Organon had argued that its orange flavor was a different orange flavor than other medicines on the market with an orange flavor. ${ }^{204}$ It argued that the orange flavor has nothing to do with the product itself. ${ }^{205}$ It did not make the product cheaper or stronger or weaker in dosage. ${ }^{206}$ It also argued that doctors when prescribing the drug do not concern themselves with the flavor of the drug. ${ }^{207}$ Organon also argued that the orange flavor did not affect the function of the medication-regardless of how it tastes, the medicine still works the same. ${ }^{208}$

The TTAB disagreed. ${ }^{209}$ The TTAB held that the orange flavor could not function as a trademark because pharmaceutical companies add flavor to their medicines on a frequent basis. ${ }^{210}$ Organon did not attempt to register a distinct flavor of orange; it attempted to register the flavor orange. ${ }^{211}$ Even if a unique flavor of orange was at issue, not only did the applicant not supply any evidence as to this flavor, but flavor itself is too subjective to be perceived in a constant way by consumers and therefore consumers could not use the flavor to distinguish Organon's products other products. ${ }^{212}$

Some predict that the recognition of flavors as trademarks may be inevitable. ${ }^{213}$ This may be possible when, as argued by Hobbs, something like an orange flavored National Law Journal becomes something people might buy. ${ }^{214}$ In the advertisements for Coke Zero, the Coke Cola Company satirizes attorneys and attempts to get fictitious legal advice that would support their clam for trademark protection of Coke Zero. ${ }^{215}$ Although humorous, the point of the

200. See infra app. C.

201. See infra app. A.

202. Nancy L. Clarke, Note, Issues in the Federal Registration of Flavors as Trademarks for Pharmaceutical Products, 1993 U. ILL L. REV. 105.

203. In re N.V. Organon, 79 U.S.P.Q.2d (BNA) 1639 (T.T.A.B. 2006).

204. Id. at 1641 .

205. Id. at 1641 .

206. Id. at 1641 .

207. Id. at 1641 .

208. Id. at 1641 .

209. In re N.V. Organon, 79 U.S.P.Q.2d (BNA) 1639 (T.T.A.B. 2006).

210. Id. at $1649-50$.

211. Id. at 1650 .

212. Id. at 1650 .

213. Michael D. Hobbs, Jr., Orange Flavor is No Trademark, NAT'L L.J., Apr. 23, 2007, at col. 1.

214. Id.

215. For a humorous take on Coke Cola attempting to obtain trademark rights to its beverage 
advertisement is obvious. Coke considers the flavor of its beverage to be an indicator of the source of its product. Coke, to date, has not yet filed a trademark application nor been a party to a reported case regarding the flavor of Coke Zero.

\section{TACTILE}

In the United States, there is one mark registered for the feel or texture of the mark. ${ }^{216}$ There have been five applications ${ }^{217}$ and only one reported case (where the plaintiff did not prevail). ${ }^{218}$ The only registered mark is owned by American Wholesale Wine and Spirits, Inc., which registered the velvet texture covering on a bottle of wine. ${ }^{219}$ This registration issued in October of $2006 .{ }^{220}$ There were two other tactile marks that were applied for registration for crystals applied to ties $^{221}$ and crystals applied to art reproductions. ${ }^{222}$ Both marks were refused registration because the marks failed to operate as a trademark and appeared to be merely decorations. ${ }^{223}$ The applicant, Karen's Krystals, Inc., did not respond to the Office Actions and so the marks were abandoned by the PTO. ${ }^{224}$ Worldwide, there appears to be only one other trademark registered claiming the feel of an appellation. ${ }^{225}$ In Germany, the word UNDERBERG in Braille for use on beer and other beverages is registered. ${ }^{226}$

known as Coke Zero and enforcing those rights against itself, see Coke sues Coke Zero for Infringement, http://www.youtube.com/watch?v=pv8YgrqUCVU (Uploaded July 26, 2006).

216. See infra app. A.

217. See infra app. A.

218. Schwinn Bicycle Co. v. Murray Ohio Mfg. Co., 470 F.2d 975 (6th Cir. 1972).

219. American Wholesale Wine \& Spirits, Inc., Reg. No. 3,155,702 (registered Oct. 17, 2006) available at http://tarr.uspto.gov/servlet/tarr?regser=serial\&entry=76634174. In April 2004, Ecuador apparently granted registration for this very mark. One description of this mark is as follows: "The mark consisted of a crackle glass texture on a bottle." Melissa E. Roth, Note, Something Old, Something New, Something Borrowed, Something Blue: A New Tradition in Nontraditional Trademark Registrations, 27 CARDOzo L. REv. 457, n. 10 (2005) (quoting World's First Texture Trademark Registered in Ecuador, 59 INTA Bulletin (Int'l Trademark Assoc., New York, N.Y.), Dec. 15, 2004).

220. American Wholesale Wine \& Spirits, Inc., Reg. No. 3,155,702 (registered Oct. 17, 2006) available at $\mathrm{http}: / /$ tarr.uspto.gov/servlet/tarr?regser=serial\&entry=76634174.

221. Karen's Crystals, Inc., Serial No. 78,439,597 (applied June 22, 2004) available at http://tarr.uspto.gov/servlet/tarr?regser $=$ serial\&entry $=78439597$.

222. Karen's Crystals, Inc., Serial No. 78,402,600 (applied Apr. 15, 2004) available at http://tarr.uspto.gov/servlet/tarr?regser=serial\&entry=78402600.

223. United States Patent and Trademark Office, Office Action, Nov. 23, 2004, available at http://tarr.uspto.gov/servlet/tarr?regser=serial\&entry=78439597 (follow "Trademark Document Retrieval" hyperlink for access to document) (denying registration of crystals applied to a tie); United States Patent and Trademark Office, Office Action, Jan. 28, 2005, available at http://tarr.uspto.gov/servlet/tarr?regser=serial\&entry=78402600 (follow "Trademark Document Retrieval" hyperlink for access to document) (denying registration of crystals applied to art reproductions).

224. See supra notes 221-22.

225. Sieckemann, Ralf, The non-traditional Trade Mark archives - tactile mark, http://www.copat.de/markenformen/Tactilemark.pdf (last visited Sept. 22, 2011).

226. Id. 
Tactile marks remain a very odd commodity for trademark offices worldwide. To date, only three applications have been filed worldwide for the feel of a mark. ${ }^{227}$ Even so, one influential commentator has noted apparently approving of tactile marks that "[i]n terms of a brand, the feeling and textures of a product can play on a consumer's emotions and can also relate directly to his or her perception of quality. 228

\section{HOLOGRAM}

As the Lanham Act and the Qualitex decision refer to "any" word, name, symbol or device, some creative entities have even attempted to apply for holograms as their trademark. ${ }^{229}$ In In re The Upper Deck Co., the Applicant attempted to register a mark it described as follows:

The mark consists of a hologram device which is applied to the goods, trading cards. The mark is discrete from and does not constitute a part of the subject matter of the trading card. Neither the size nor the shape of the hologram device, nor any content which may be represented within the hologram device, nor the positioning of the hologram device on the trading card are claimed as features of the mark. ${ }^{230}$

This application was denied by the TTAB on the grounds that the holographic device failed to function as a trademark. ${ }^{231}$ Additionally, by definition a holographic mark would be perceivable from multiple angles and therefore more than one view of the mark here was applied for registration, the TTAB found that this necessitated the finding that more than one mark was applied for registration, something that the Lanham Act prohibits. ${ }^{232}$ That is, the Applicant was attempting to register the idea of a hologram on playing cards, not a specific, single mark. ${ }^{233}$ Based on this understanding of the interaction between the Lanham Act and holographic marks, it is difficult to see how a holographic mark could ever be registered.

However the PTO has registered 11 of 19 applications for trademarks that consist of a hologram. ${ }^{234}$ Thirteen of the 19 applications have been abandoned or cancelled for nonuse. ${ }^{235}$ It takes an average of almost 30 months to convince the PTO that a hologram mark should be registered. ${ }^{236}$ Once again, the data does

227. See supra Part VIII.

228. Jerome Gilson \& Anne Gilson LaLonde, Cinnamon Buns, Marching Ducks and CherryScented Racecar Exhaust: Protecting Nontraditional Trademarks, 95 TRADEMARK REP. 773, 801 (2005).

229. In re The Upper Deck Co., 59 U.S.P.Q.2d (BNA) 1688 (T.T.A.B. 2001).

230. Id. at 1689 .

231. Id.at1691-92.

232. Id. at 1689-91.

233. Id. at 1689-91.

234. See infra app. A

235. See infra app. C.

236. See infra app. D. 
not support the conclusion that hologram marks are a significant part of the American trademark universe. There were no reported cases where a hologram mark was the subject of the trademark litigation.

\section{MOTION}

In 1957, the PTO granted a registration for the motion of a coin spinning on top of a hard surface to connote a particular Bank in Duluth, Minnesota. ${ }^{237}$ This is one of the earliest registered nontraditional trademarks in America. ${ }^{238}$ Since then, the PTO has granted registrations for motion marks such as preprogrammed search lights projected into the sky for use on search lights, ${ }^{239}$ to promote public awareness of the negative effects of smoking, a "stylized capital letter ' $Y$ ' within a loosely defined circle orbited clockwise by a second, smaller, loosely defined circle containing a stylized question mark, ${ }^{240}$ and, to beat all, for use on automobiles, the motion of a Lamborghini car door opening vertically rather than horizontally. ${ }^{241}$

There are apparently three types of motion trademarks. The first is computer generated moving image marks such as Nokia's Community Trademark registration described as "The mark comprises an animation which consists of four images depicting hands coming together, shown in succession from left to right and from top to bottom." ${ }^{242}$ The second type of motion marks consists of the motion of the product itself as in the vertical motion of the Lamborghini door $^{243}$ or the fan-shaped spray that leave the back of a Yamaha personal watercraft. ${ }^{244}$ The third type of motion mark is a hand gesture. ${ }^{245}$

The complexity of claiming motion as a trademark came to a head in the Diamond Cutter dispute with Jay-Z. ${ }^{246}$ A former TV variety professional

237. Northwestern Bank of Commerce, Reg. No. 641,872 (Registered Feb. 19, 1957) available at http://tarr.uspto.gov/servlet/tarr?regser=serial\&entry=71691883.

238. Id.

239. Ballantyne of Omaha, Inc., Reg. No. 2,323,892, available at_http://tarr.uspto.gov/servlet/ tarr?regser=serial\&entry $=75627000$.

240. Virginia Tobacco Settlement Foundation, Reg. No. 2,709,214, available at http://tarr.uspto.gov/servlet/tarr?regser=serial\&entry $=76427250$.

241. Automobile Lamborghini Holding S.p.A., Reg. No. 2,793,439, available at http://tarr.uspto.gov/servlet/tarr?regser=serial\&entry=75883661.

242. Nokia Corporation, Community Trademark Reg. No. 3,429,909, available at http://oami.europa.eu/CTMOnline/RequestManager (search for Trade mark No. 3429909).

243. See supra note 26.

244. Yamaha Hatsudoki Kabushiki Kaisha, Reg. No. 1,946,170, available at $\mathrm{http}: / /$ tarr.uspto.gov/servlet/tarr? regser=serial\&entry=74321288.

245. For further documentation of these and other motion marks and some extremely helpful analysis, see Lesley Matty, Note, Rock, Paper, Scissors, Trademark? A Comparative Analysis of Motion as a Feature of Trademarks in the United States and Europe, 14 CARDOZO J. INT'L \& CoMP. L. 557 (2006).

246. Plaintiff Diamond Dallas Page's First Amended Complaint for (1) Trademark Infringement; (2) False Designation of Origin; (3) Federal Dilution; (4) Unfair Competition; (5) Injury to Business Reputation; (6) Copyright Infringement (7) Misappropriation of Trade and 
wrestler by the name of Page Falkinburg, whose wrestling name was "Diamond Dallas" claimed to have coined and adopted as a trademark a hand gesture that can best be described as attempting to make a diamond shape out of one's two hands. ${ }^{247}$ To make the gesture, with open hands, face your palms out. Then, bring your forefingers and thumbs together just so they touch. If you do that, Diamond Dallas claims you have infringed his trademark. ${ }^{248}$ This is the gesture that Jay- $\mathrm{Z}$ made in a picture on an album cover and so Diamond Dallas filed suit. ${ }^{249}$

This is a perfect example of why the TTAB's objection to holographic marks ought to apply to motion marks as well. That is, Diamond Dallas is claiming a trademark in the idea of a hand gesture rather than a specific mark that can be identified. ${ }^{250}$ Therefore, motion marks should not be registered and should be unenforceable.

There are actually 18 total trademark applications for motion marks and 13 subsisting registrations. ${ }^{251}$ It takes a mere 20 months to obtain trademark registration status for a motion. ${ }^{252}$ There were no reported cases where a motion mark was the subject of the litigation.

\section{THE SKY IS THE LIMIT}

With the venerable explosion of interest in nontraditional trademarks, applicants and claimants alike in the United States are interpreting "any" to really mean "any." Therefore, if distinctive and not functional, one wellrespected commentator claims that even "sales techniques" would be appropriate subject matter for trademark protection. Gilson claims as follows:

adoption procedures for Cabbage Patch Dolls were found to be protectable trade dress as were the layout and overall appearance of mail-order catalogs and a sales brochure, car service reminder letters and the "combination and arrangement" of features in a sales report. Advertisements for sunglasses with actors posing as vampires--and other vampire-related marketing--were found to be protectable trade dress, as was the overall image of Marlboro cigarette advertising. ${ }^{253}$

Commercial Value, Diamond Dallas Page v. Shawn Carter, No. CV05-08475 DSF (JWJx), (C.D. Cal. Dec. 6, 2006), 2006 WL 4047404.

247. Id. at para. 18.

248. See supra note 246.

249. See supra note 246 .

250. Moreover, even if the hand gesture is a valid trademark, rap singers do not compete with professional wrestlers and so confusion would be impossible to establish.

251. See infra app. A.

252. See infra app. D.

253. Jerome Gilson \& Anne Gilson LaLonde, Cinnamon Buns, Marching Ducks and CherryScented Racecar Exhaust: Protecting Nontraditional Trademarks, 95 TRADEMARK REP. 773, 81617 (2005). 
If you cannot use a cowboy or scary people wearing sunglasses without violating someone else's trademark rights, I submit that we have taken what used to be a firmly grounded right of prior appropriation to support and maintain fair competition and moved it right past the stratosphere and right to the mesosphere. ${ }^{254}$ As one reporter has put it, "What's next? A fee for looking?"255

\section{HARMONIZATION}

There are three competing understandings of the word "harmonization." On one hand, it could mean an effort to make all trademark law in the world uniform so that trademark owners know the bounds of protection anywhere in the world by understanding the laws of one country, thereby allowing trademark owners a higher degree of confidence in the worldwide market. ${ }^{256}$ It might also be understood to provide "an approximation of different rules in order to minimize any conflict that their differences might generate; . . . not necessarily imply[ing the] replication of rules." 257 Or harmonization may mean an effort to create a relationship between things that implies the creation of accord or consonance. ${ }^{258}$

One way or the other, the comments herein are equally applicable to each and every definition of or motivation for harmonization.

\section{A. Civil Law}

The Civil Law of trademarks is oriented on the registration system and more oriented to the benefit of the trademark owner. ${ }^{259}$ Trademark rights subsist upon registration. ${ }^{260}$ With few exceptions, ${ }^{261}$ without registration, the trademark right does not exist. ${ }^{262}$ In Japan, for example, the most common word for "trademark"

254. A further example is the registered mark of a British female face for use on educational services. See Sally Ramage, Reg. No. 3,440,915 available at http://tarr.uspto.gov/ tarr? regser=serial\&entry $=79 \% 2 \mathrm{~F} 035414$ \&action=Request + Status ("The mark consists of the color brown appears in the woman's eyes and portions of her hair, the color red appears in portions of her hair, the color pink appears in her lips, and the color tan appears in the woman's face and neck.").

255. David W. Dunlap, What Next? A Fee For Looking?, N.Y. Times, Aug. 27, 1998, at F1.

256. Arthur Rosett, Unification, Harmonization, Restatement, Codification and Reform in International Commercial Law, 40 AM. J. CoMP. L. 683 (1992).

257. Stephen Zamora, NAFTA and the Harmonization of Domestic Legal Systems: The Side Effects of Free Trade, 12 ARIZ. J. INT'L \& COMP. LAW 401, 427 (1995).

258. Martin Boodman, The Myth of Harmonization of Laws, 39 AM J. CoMP. L. 699, 700-02 (1991).

259. Terrance J. Keenan, American and French Perspectives on Trademark Keying: The Courts Leave Businesses Searching for Answers, 2 SHIDLER J. L. COM. \& TECH. 14 (2005)..

260. Michel J. Ayer, Why the Time Has Arrived to Broaden Protection of Foreign Trademarks in the United States and Why it Won't Happen, 32 J. CoRP. L. 927, 935 (2007).

261. These exceptions come in the form of limited rights granted to the first user of a mark that becomes famous without registration. In such a setting, subsequent registrants must accept and

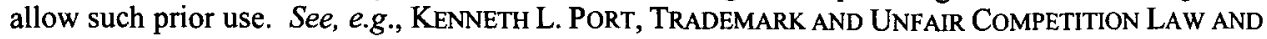
POLICY IN JAPAN 85-90 (2007) (discussing the effect of use in Japan).

262. Max Vern, A Trademark Visa -- Aspects of International Trademark Use and Protection, 
(shohyo) is not even used to describe an appellation of source unless it is registered. ${ }^{263}$

The criteria for registration are very plainly spelled out. The various Civil Law trademark statutes state the specific types of trademarks that may be registered and those that may not be registered. ${ }^{264}$ Although a WIPO survey indicates that many Civil Law countries allow registration of nontraditional trademarks, very few actually have registered significant numbers of nontraditional trademarks. ${ }^{265}$

Since the inception of the CTM system in $1996,{ }^{266}$ there has been some application activity for nontraditional marks in, for example, the Community Trademark system for the European Union. The data on CTM applications for nontraditional trademarks post 1996 is as follows. ${ }^{267}$

88 J. PAT. \& TRADEMARK OFF. SOC'Y 847, 848 (2006).

263. Kenneth L. Port, Trademark and Unfair Competimion Law and Policy in Japan 95 (2007).

264. See Trademark Act, Law No. 127 of 1959, arts. 3-4 (Japan), translated and available at http://www.japaneselawtranslation.go.jp/law/detail/?id $=45 \& \mathrm{vm}=04 \&$ re $=02$ (prescribing six types of things that can be registered and 19 types of marks that may not be registered in Japan); Article L711-1 (France) available at http://195.83.177.9/upl/pdf/code_35.pdf (providing three examples of marks worthy of registration). The EU denied the registration of a mark that consisted of "balsamic fruity scent with a slight hint of cinnamon" for educational services and food and drink because the chemical formula did not satisfy the technical requirement that the mark be able to be depicted graphically. Case C-273/00, Sieckmann v. Deutsches Patent- und Markenamt, 2002 E.C.R. I11737 , available at $\mathrm{http}: / /$ curia.europa.eu/jcms/jcms/j_6/ (search for Case C-273/00).

265. See, e.g. 1) The Braille form of UNDERBERG in Germany for use on beer, http://www.copat.de/markenformen/Tactilemark.pdf; 2) The feel of a velvet patch on a wine bottle in Ecuador, Melissa E. Roth, Note, Something Old, Something New, Something Borrowed, Something Blue: A New Tradition in Nontraditional Trademark Registrations, 27 Cardozo L. REv. 457, n. 10 (2005) (quoting World's First Texture Trademark Registered in Ecuador, 59 INTA Bulletin (Int'l Trademark Assoc., New York, N.Y.), Dec. 15, 2004.).

266. The Community trademark (CTM) system was introduced in 1996 by The Trade Marks and Designs Registration Office of the European Union (OHIM). CTM covers the entire European Union and is valid in all 27 Member States. To date there are approximately 600,000 CTM registered trademarks. The Trade Marks and Designs Registration Office of the European Union, Trade Marks, http://oami.europa.eu/ows/rw/pages/CTM/index.en.do..

${ }^{267}$ Color marks are excluded because the database does not differentiate between color alone marks and color as an attribute of the mark. This study regards color alone as a mark. See The Trade Marks and Designs Registration Office of the European Union: CTM-ONLINE - Trade Mark Consultation Service - Basic, http://oami.europa.eu/ CTMOnline/RequestManager/en_SearchBasic (last visited Sept. 22, 2011) (searchable database does not allow searching for color alone as a mark). 

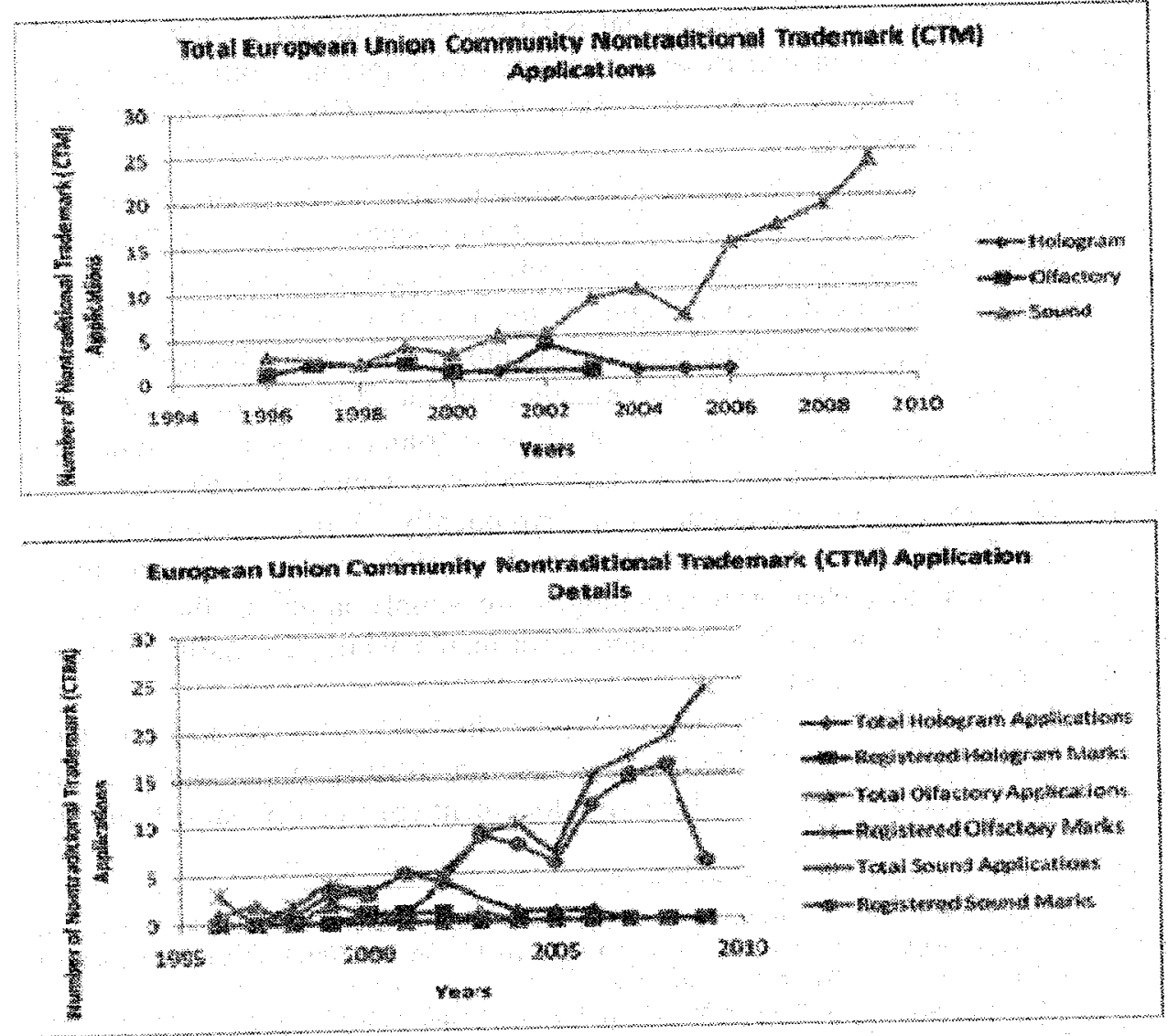

The two things in this graph that are striking are that the number of sound marks issued has dropped significantly and that the number of sound marks applied for has risen sharply. This inverse relationship between the number of applications for sound marks and the number that are actually registered is indicitive of the lack of experience Civil Law countries have with examining nontraditional trademarks.

To allow the registration of nontraditional trademarks (or any trademark whatsoever), the Civil Law requires a specific statute stating the specific type of mark to be registered. This is because one can say that Civil Law systems, in general, are far more positivist in orientation than the Common Law system of the United States. ${ }^{268}$ In Civil Law systems, judges do not make law, they

268. Errol E. Meidinger, Learning Sustainability, 10 Buff. EnvTL. L.J.211, 253 (2003); Alan Uzelac, Comparative Theme: UNCITRAL Notes on Arbitral Proceedings: A Regional View, 4 CROAT. ARB. Y.B. 135, 153 (1997); Karen Engle, Comparative Law as Exposing the Foreign System's Internal Critique: An Introduction, 1997 UTAH L. REv, 359, 362 (1997) (quoting MarieClaire Belleau, The "Juristes Inquiets": Legal Classicism and Criticism in Early Twentieth- 
interpret and apply it. ${ }^{269}$ Although that is an overly broad generalization that is used as a litmus test in confirmation hearings of Supreme Court nominees ${ }^{270}$ before the United States Senate, it is more accurate in Civil Law jurisdictions than in the United States.

Trademark statutes in Civil Law jurisdictions are written with precision so that interpretation is not necessary. ${ }^{271}$ If a statute needs to be interpreted, it is synonymous with saying that that statute needs to be revised or amended. ${ }^{272}$

Civil Law systems do not recognized the notion of stare decisis. ${ }^{273}$ As judges are only supposed be applying the statute in a more mechanical manner, there is no need for judges to look for guidance outside of the statute itself.

Most Civil Law systems would not allow a trial by jury for a trademark violation. Rather, the initial trial would be before a panel of three judges. In many Civil Law systems, judges are rotated frequently. ${ }^{274}$ It is common during a long trial to have different judges rotate in and out of the panel. ${ }^{275}$ As judging is a more mechanical endeavor where judges are simply applying the statue as written to any given set of facts, it should not matter who, personally, might be on trial panel.

Discovery in Civil Law systems is quite limited. ${ }^{276}$ As pleading is factbased ${ }^{277}$ plaintiffs are not allowed to go on fishing expeditions during discovery. ${ }^{278}$ Litigants must produce any document specifically named, but, for

Century France, 1997 UTAH L. REv. 379, 379 (1997)). See also JOHN HENRY MERRYMAN \& Rogelio Pérez-Perdomo, THe CIVIL LAW Tradition 16-17 (3d ed. 2007) (comparing common and civil law perspectives on interpreting the law).

269. Antonio Gidi, Class Actions in Brazil-A Model for Civil Law Countries, 51 AM. J. CoMP. L. 311,318 n.9 (2003); Rett R. Ludwikoski, Latin American Hybrid Constitutionalism: The United State Presidentialism in the Civil Law Melting Pot, 21 B.U. INT'L L.J. 29, $45-46$ (2003); MERRYMAN \& PÉREZ-PERDOMO, supra note 268, at 88-89.

270. See, e.g, Confirmation of Ruth Bader Ginsburg as Supreme Court Justice Before S. Judiciary Comm., 103d Cong. (1993) [hereinafter Confirmation Hearing] (Ruth Bader Ginsburg stated that judges do not make law, they interpret and apply the law).

271. MERryman \& PÉrEz-PERDOMO, supra note 268, at 61 (law is a precise science and should be able of clear communication. "The law is thus enriched, and enriched by a purely scientific method") (quoting RUDOLPH SOHM, THE INSTITUTES: A TEXTBOOK OF THE HISTORY AND SYSTEM OF Roman Private Law 30 (James Crawford Ledlie, trans., Erwin Grueber ed., 3d ed. 1907)).

272. MERR YMAN \& PÉREZ-PERDOMO, supra note 268, at 39-47.

273. MERRYMAN \& PÉREZ-PERDOMO, supra note 268, at 45-47.

274. J. Mark Ramseyer, Reluctant Litigant Revisited: Rationality and Disputes in Japan, $14 \mathrm{~J}$. JAPANESE STUD. 111, $116 \mathrm{n} .16$ (1988).

275. Id. (stating that judges are rotated "frequently.")

276. See Craig P. Wagnild, Civil Law Discovery in Japan: A Comparison of Japanese and U.S. Methods of Evidence Collection in Civil Litigation, 3 AsIAN-PACIFIC L. \& POL'Y J. 1 (2002); KuoChang Huang, INTROducing Discovery INTO CIVIL LAW (2003) (comparing discovery in the United State to civil law jurisdictions).

277. See Mirjan Damaska, Presentation of Evidence and Factfinding Precision, 123 U. PA. L. REV. 1083, 1088-89 (1975) (discussing role of the judge in gathering facts); Benjamin Kaplan et al., Phases of German Civil Procedure I, 71 HARv. L. REv. 1193, 1234-35 (1958) ("proof-taking is conducted mainly by the court" in Germany).

278. See Stephen N. Subrin, Discovery in Global Perspective: Are We Nuts?, 52 DePaUl L. 
example, defendants are never asked open-ended interrogatories ${ }^{279}$ or requests for documents ${ }^{280}$ for which one would need a truck to deliver the responses. ${ }^{281}$

The appeal process in Civil Law countries is a continuation of the original trial. ${ }^{282}$ Once the trial court comes to a conclusion, the appellate court retries the case. $^{283}$ One can produce new evidence, give different responses, change the theory of the case, etc. ${ }^{284}$ Litigants are not bound to the trial record of things said. ${ }^{285}$ Therefore, there is no concept of standard of review when a Civil Law appellate court considers a trial court outcome. ${ }^{286}$ In fact, because judges rotate, in a lengthy trial, it is not uncommon for a trial court judge to be reassigned to the appellate bench while the appeal is pending. ${ }^{287}$ Such a Civil Law judge would not recuse him or herself. ${ }^{288}$ Rather, this judge would join the appellate bench for an appeal of a trial that judge tried.

In Civil Law countries, trademark related surveys are either non-existent or not relied on anywhere near as much as in the United States. ${ }^{289}$ As such, a Civil Law judge may only hear about how the public views the mark, whether they would be confused by a competing use, or how strong the mark is from the litigants themselves. ${ }^{290}$ Surveys are considered far too unreliable to be used in a

REV. 299 (2002); Elizabeth G. Thomburg, Just Say "No Fishing”: The Lure of Metaphor, 40 U. MICH. J.L. REFORM 1 (2006) (criticizing describing discovery as a "fishing expedition.").

279. See KUO-CHANG HUANG, INTRODUCING Discovery INTO CIVIL LAW 207-08 (2003) (restriction on interrogatories intended to prevent overly broad "fishing expeditions").

280. See also Brendan Sweeney, The Role of Damages in Regulating Horizontal Price-Fixing: Comparing the Situation in the United States, Europe and Australia, 30 MELBOURNE U. L.R. 837 (2006) (the job of collecting documents is a judicial function).

281. See, e.g., Class Action (InterScope Communications 1991) (A film starring Gene Hackman where the defense attempts to bury the plaintiff in a mountain of discovery to try to win the case).

282. Douglas C. Smith, Structural and Functional Aspects of the Jury: Comparative Analysis and Proposals for Reform, 48 Ala. L. Rev. 441, 460-61 (1997).

283. Id. at $460-61$.

284. Id. at $460-61$..

285. Id. at 461 .

286. See John H. Langbein, The German Advantage in Civil Procedure, 52 U. CHI. L. REV. 823 , 855-58 (1985) (stating that there is "[n]o presumption of correctness attaches to the initial judgment" in German appellate courts.)

287. See Ramseyer, supra note 274 , at 116 n. 16 (stating that Japanese judges rotate "frequently").

288. But see Nicolas Marie Kublicki, An Overview of the French Legal System from An American Perspective, 12 B.U. INT'L L.J. 58, 64 n. 34 (1994) (quoting Article 731-1 of the French Code of Judicial Organization which requires a judge to recuse oneself if one previously heard the case.); Chuichi Suzuki, Problems of Disqualification of Judges in Japan, 18 AM. J. CoMP. L. 727, 729 (1970) (Japanese judges disqualified if participated in trial).

289. Yuriko Inoue, Kondo no osore no rissho to anketochosa [Proof of Likelihood of Confusion and Surveys], in Chitekizaisan no Choryu [Current Trends in Intellectual Property] (Institute of Intellectual Property ed., 1995).

290. See, e.g., Sony KK v. Yugn Kaisha Walkman, 1598 Hanrei Jiho 142 (Chiba Dist. Ct., April 4, 1996)(relying on a survey proffered by Sony to find confusion between Walkman cassette players and shoes), translated in Kenneth L. Port, Japanese Intellectual Property Law in Translation: Representative Cases and Commentary, 34 VANDERBILT J. TRANS. L. 847, 856-867 (2001). 
court of law. ${ }^{291}$ On the other hand, individual judges make up their own mind regarding these questions. ${ }^{292}$ Therefore, it is not unusual in Civil Law jurisdictions for judges to reach decisions that are clearly not responsive to general public perception. ${ }^{293}$ Considering there are no juries, this means that the only way for a judge to answer whether the mark is strong, for example, is to look at the evidence him or herself and reach a conclusion. ${ }^{294}$

The reason it is more appropriate to treat trademarks in such a positivist manner is because Civil Law jurisdictions consider the trademark itself as property. ${ }^{295}$ When one owns a registration one owns a trademark. There is no distinction conceptually made between the trademark and the trademark right. All rights in trademarks are determined by the scope of the classification of goods or services claimed in the registration itself. ${ }^{296}$ It would be appropriate to say that a trademark owner owns the right to use the mark on all goods in the classification for which it is registered.

That is, trademarks in Civil Law jurisdictions are corporeal things. Civil Law judges do not make tortured analogies to "quasi property rights" as they do in the United States. ${ }^{297}$ Trademarks are property, period.

The theory that trademarks are property is doctrinally evidenced by the fact that trademark rights in Civil Law jurisdictions are severable. ${ }^{298}$ A trademark

291. Yuriko Inoue, Kondo no osore no rissho to ankeitochosa [Proof of Likelihood of Confusion and Surveys], in Chitekizaisan no Choryu [Current Trends in Intellectual Property] (Institute of Intellectual Property ed., 1995).

292. See Merryman \& PéreZ-PERdomo, supra note 268, at 117-18 (explaining that civil judges both gather and weigh evidence).

293. Cf. Gibson Guitar Corp. v. Fernandes, KK, 1719 Hanrei Jiho 122 (Tokyo High Ct., Feb. $24,2000)$ ("Les Paul" guitar shape is generic), translated in Kenneth L. Port, Japanese Intellectual Property Law in Translation: Representative Cases and Commentary, 34 VANDERBILT J. TRANS. L. 847, 856-867 (2001) with Gibson Guitar Corp. v. Paul Reed Smith Guitars, LP, 423 F.3d 539 (6th Cir. 2005) (consumers likely to experience initial confusion due to identifying shape but not pointof-sale confusion).

294. See Merryman \& Pérez-Perdomo, supra note 268, at 117-18 (explaining that civil judges both gather and weigh evidence).

295. For Japan, see Makoto Amino, Shohyo (Trademarks) 47 (1992); for France, see Article L713-1 available at http://195.83.177.9/upl/pdf/code_35.pdf("Registration of a mark shall confer on its owner a right of property. ..").

296. For France, see L. 713-1 available at http://195.83.177.9/upl/pdf/code_35.pdf ("Registration of a mark shall confer on its owner a right of property in that mark for the goods and services he has designated.").

297. See, e.g., Pennzoil Co. v. Crown Cent. Petroleum Corp., 50 F. Supp. 891, 900 (D. Maryland 1943) ("in the modern law of business colorable imitation of a trade-mark is prejudicial to the quasi-property interest in the trade-mark itself especially where it has been much advertised."); AutoZone, Inc. v. Tandy Corp., 373 F.3d 786, 801 (6th Cir. 2004) (“Dilution law, unlike traditional trademark infringement law . . . is not based on a likelihood of confusion standard, but only exists to protect the quasi-property rights a holder has in maintaining the integrity and distinctiveness of his mark.") (quoting Kellogg Co. v. Toucan Golf, Inc., 337 F.3d 616628 (6th Cir. 2003)); Bonito Boats Inc. v. Thunder Craft Boats, Inc., 489 U.S. 141, 157 (1989) (a trademark owner has at best a "quasi-property right" in its mark); Frank Schechter, The Rational Process of Trade-Mark Protection, 40 HARV. L. REV. 813, 831-32 (1927) (comparing treatment of a mark in different jurisdictions). 
owner in a Civil Law country can sell the same mark to one entity to make bicycles and another entity to make cameras. The quality control of a licensee's trademark use need not be supervised by the licensor in Civil Law countries. ${ }^{299}$ There is no tracking of the goodwill. Trademarks can be assigned in gross and used under naked licenses. ${ }^{300}$ Doctrinally, trademarks act like property in Civil Law countries.

Therefore, as property, trademarks in Civil Law countries are far harder to obtain and far more difficult of which to be divested. Although the trademark registration process itself in Civil Law jurisdictions is no more arduous than in the United States and usually much easier, ${ }^{301}$ the very fact is that one must obtain a trademark registration before one "owns a trademark."

As such, there are very high transaction costs involved in Civil Law countries that are not recognized in the United States. There is a very high cost of knowledge. A user of a trademark has to, somehow, know or learn that a registration must be filed. The cost of this knowledge is not measurable. Additionally, an entity that wishes to own a trademark has to hire a lawyer (or other specialist) to file the trademark application. It would be a very unlikely occurrence for a private individual to file a trademark application pro se in Civil Law countries.

Once registered, no Civil Law trademark office has the authority to cancel trademarks on their own motion for something like nonuse. ${ }^{302}$ It takes a specific motion by a party who now wants to use and register the mark to obtain a cancellation for nonuse. ${ }^{303}$ That is, in order to obtain a registration and in order to maintain the trademark, use need never occur. Usually, three years of nonuse opens the door for aggrieved parties to file a motion to cancel a trademark for nonuse. ${ }^{304}$ The evidentiary burden is similarly high for other common reasons to

298. For Japan, see Japanese Trademark Act, art. 24(1) available at http://www.japaneselawtranslation.go.jp/law/detail/?id $=45 \& v m=02 \& \mathrm{re}=02 \& \mathrm{nnew}=1$ ("trademark right may be divided for each of the designated goods"); for France, see Law No. 92.597 of July 1, 1992, on the Intellectual Property Code (Legislative Part) as last amended by Law No. 94-102 of February 5, 1994, book 7, title 1, chapter 4, L. 714-1 available at http://195.83.177.9/ upl/pdf/code_35.pdf ("The rights under a mark may be transferred in whole or in part, independently of the company that exploits them or

has them exploited.").

299. For Japan, see Kazuko Matsuo, Trademarks, in 4 Doing Business in Japan Sec. 6.01 - Sec. 6.12 (Zentaro Kitagawa ed., 2007) (entire chapter of treatise on licensing intellectual property in Japan and never mentions quality control).

300. See Kazuko Matsuo, Intellectual Property Protection, Doing Business in Japan $\S 6.01[\mathrm{~d}]$ (Zentaro Kitagawa ed., 2009) ("The prior rule that assignment of a trademark independent of the business good will concerned was not permitted was abolished, permitting freer transfer of registered trademarks."); Makoto Amino, Shohyo [Trademarks] 647-54 (1995).

301. See Kazuko Matsuo, 3-6 Doing Business in Japan $\S 6.03$ (Zentaro Kitagawa ed., 2009) (discussing process).

302. See Kazuko Matsuo, 3-6 Doing Business in Japan § 6.03[8] (Zentaro Kitagawa ed., 2009) (must request cancellation).

303. Id.

304. Japanese Trademark Law, art. 50-1, available at http://www.japaneselawtranslation.go.jp/ 
petition a trademark to cancel a trademark registration such as nondistinctiveness or functionality.

Because the trademark in Civil Law countries is property, it is harder to lose, harder to obtain and more easily confused. That is, in Civil Law countries, trademarks are construed much more broadly than in the United States.

The Civil Law of trademarks find their origin in providing businesses an ability to protect their "signs" as corporeal rights. ${ }^{305}$ The origin of the Common Law trademark is to prevent a consumer from being confused. ${ }^{306}$

The Civil Law of trademark jurisprudence focuses on the functions of trademarks. When a function of the trademark is harmed, the Civil Law world calls that trademark infringement. ${ }^{307}$

The first function of trademarks is the source indicating function. ${ }^{308}$ This is the only role that trademarks play in the United States. ${ }^{309}$ This function allows the trademark claimant to use the mark to indicate that it is the sole creator of the good or service to which the mark is attached.

The second function is the quality guarantee function. ${ }^{310}$ By using the same trademark on the same goods or services, customers can rely on the fact that the quality of the goods or services will be consistent. Not that the quality will be

law $/$ detail $/$ id $=45 \& \mathrm{vm}=02 \& \mathrm{re}=02 \&$ new $=1$

305. See Terrance J. Keenan, American and French Perspectives on Trademark Keying: The Courts Leave Businesses Searching for Answers, 2 SHIDLER J. L. COM. \& TECH. 14, P24-P25 (2005) (French "trademark rights are akin to property rights"); Rudolf Rayle, The Trend Towards Enhancing Trademark Owners' Rights-A Comparative Study of U.S. and German Trademark Law, 7 J. INTELL. PROP. L. 227, 270 (2000) ("[t]rademarks in Germany are property").

306. See Timothy W. Blakely, Beyond the International Harmonization of Trademark Law: The Community Trade Mark as a Model of Unitary Transnational Trademark Protection, 149 U.PA. L.REv. 309, 309 (2000) (stating that traditionally, trademarks were "understood to indicate the origin of a product.").

307. KenNeth L. PoRt, Trademark AND Unfair Competition IN JAPAN 6 (2007).

308. Shoen Ono, Overview of Japanese Trademark Law, Chapter 5, p. 7-8 (1992) translated and available at http://www.iip.or.jp/e/e_publication/ono/index.html (chapters are not consecutively numbered); Makoto Amino, Shohyo (Trademarks) 71-2; Ethan Horwitz, FRA-3 World Trademark Law and Practice, France § 3.01 (Mathew Bender, Rev. ed.) (In French law, "the sole condition [of trademark validity] is that it must be distinctive with respect to the articles it identifies," citing Mathely, Letter from France, (1969)).

309. See Radiance A. Walters, Partial Forfeiture: The Best Compromise in Trademark Licensing Protocol, 91 J. Pat. \& TRademark OFF. Soc'Y 126, 128 (2009) ("According to the statute, the purpose of a trademark is to identify a good or service to the consuming public and ensure consistency in quality.").

310. Shoen Ono, Overview of Japanese Trademark Law, Chapter (1999) translated and available at http://www.iip.or.jp/e/e_publication/ono/index.html (chapters are not consecutively numbered); Makoto Amino, Shohyo (Trademarks) 73-74; 2-3 Ethan Horwitz, World Trademark Law and Practice $\S 3.01$ (Mathew Bender, Rev. Ed.) (Under German law, trademarks "must be likely to serve the consumer as a means of recognizing the goods of the applicant and to distinguish those goods from the goods of competitors. A mark cannot be registered if it is not capable of distinguishing the goods upon which it appears, if it consists solely of figures or letters, or if it consists of words which indicate the kind, time and place of production, the nature, purpose, price, quantity or weight of the goods.") (citations omitted). 
good or bad, just consistent. Therefore, a handbag purchased at JC Penny will have different quality expectation than one purchased at Coach.

The third function is the consistent good function. ${ }^{311}$ When a specific trademark is used, the consumer can immediately recognize that a specific good or range of goods is associated with the use of this mark. Therefore, when a consumer sees the trademark Kodak, the consumer knows that the range of goods associated with that mark will somehow include something to do with cameras. In the United States, when the producer creates a close association between the good and the trademark, the mark will be rendered generic. ${ }^{312}$ In Civil Law countries, this ability to broadly protect the good's function renders the dilution doctrine unattractive.

Finally, the advertising function of trademarks is of growing import. ${ }^{313}$ The use of trademarks plays a very important role in advertising a good or service. Take Coach purses, for example. Just saying the word "Coach" connotes expensive and luxurious purses and handbags for women. Coach need not say

311. Shoen Ono, Shohyoho (Trademark Law) 49 (1994); Makoto Amino, Shohyo (Trademarks) 774-75. A Danish decision from 1983 held that confusingly similar names could were both eligible for registration as trademarks because the two companies were in totally different fields, thus there would be no confusion of one product line with another. 2-3 Ethan Horwitz, World Trademark Law and Practice, Denmark $\S 3.07$, n. 16 (Mathew Bender, Rev. Ed.) ("A trade mark can only stop the registration of a company name if the company actually is doing business with identical or similar goods or services for which the trade mark is registered but a trade mark registration can only stop a person using the trade mark as a name if the trade mark has been put on the official list of names. The rights to names and trade marks are obviously not reciprocal, but the rights derived from names are on the other hand more narrow in scope, as identity or near-identity until now has been paramount to the ability to stop infringing use or abuse of a name or a trade mark. In this connection, it seems that a trade mark registration combined with the provisions under the law protecting names would form the best possible protection in Denmark for trade marks derived from eg a company name, a founder's name etc. It should be considered desirable to register secondary names for registered companies or to put the registered trade mark on the official list of names as identical trade marks are then prevented from being used even for different goods or services.") (quoting Memorex A/S v. Memotak, ApS, decision of the Supreme Court dated February 15, 1983, UfR 1983, 341, [1983] EIPR D-247.).

312. See, e.g., King-Seeley Thermos Co. v. Aladdin Industries, Inc., 321 F. $2 \mathrm{~d} 577$ (2d Cir. 1963) (the product named "thermos" became the word used to describe a vacuum-insulated container that would keep beverages hot or cold and thus was generic).

313. See Shoen Ono, Shohyoho (Trademark Law) 49 (1994); Makoto Amino, Shohyo (Trademarks) 74-75. Argentina has struggled repeatedly with the importance of advertising in trademark law. Aracama Zorraquin describes the evolution of the law this way: "Those who are familiar with the evolution of Argentine case law concerning the protection of advertising phrases (slogans) will remember that for a time such phrases were accepted as being registrable under trademark law. A subsequent development brought about the prohibition of their registration as such, whereupon case law, after reverting to the original position, progressed towards a situation where phrases of advertising character had to be protected by Law No. 11, 723 on Copyright, whereas those that possessed distinctive character were to be protected by the Law on Trademarks. This distinction, which is highly subjective and very difficult to make in practice, has been removed by the new Law, which allows registration as trademarks of phrases for advertising purposes that meet the requirements of registrability specified by the Law on Trademarks." 1-3 Ethan Horwitz, World Trademark Law and Practice, Argentina $\$ 3.01$, n. 11 (Mathew Bender, Rev. Ed.) (citing Ernesto Aracama Zorraquin, New Legislation in Argentina, 1982 Ind. Prop. 88, 93). 
anything about their product. Just saying the word is enough. Even lesser known, less expensive brands of purses utilize the advertising function of trademarks. As producers attempt to raise brand awareness and make sales, they focus on the use of their trademark to operate as a short cut to their reputation, whether they are a high-end producer or not.

Civil Law countries protect these functions of trademarks. Harming any one of these functions results in a claim of trademark infringement. That is, the trademark right in Civil Law countries is far broader than in the United States.

The protection of nontraditional trademarks in a Civil Law system is problematic because of the need to be able to depict marks graphically. In the United States, a verbal description of a scent mark, for example, sufficed; ${ }^{314}$ however, in the CTM and before German judges, a chemical formula of a scent was deemed insufficient. ${ }^{315}$ Under TRIPS, "members may require, as a condition of registration, that signs be visually perceptible." ${ }^{\text {"316 }}$ Civil Law systems and the CTM take this rather literally.

However, the graphic representation requirement is satisfied by a "stave divided into measures and showing, in particular, a clef, musical notes and rests whose form indicates the relative value and, where necessary accidentals." ${ }^{, 317}$ Color may satisfy the graphic representation requirement if an "internationally recognized identification code" is used. ${ }^{318}$

\section{B. Common Law (United States) ${ }^{319}$}

Essentially, each element of the mini-primer on the Civil Law of trademarks from above is answered in the diametric opposite when in the United States. All

314. In re Celia Clarke, dba Clarke's OSEWEZ, Serial No. 758,429, Trademark Trial and Appeal Board, 1990 TTAB LEXIS 53; 17 U.S.P.Q.2D (BNA) 1238, September 19, 1990.

315. Sieckmann v. Deutsches Patent-Und Markenamt, Eurpean Court of Justice, Case C273/00, 2002 E.C.R. I-11737. See also, Eli Lilly \& Co.'s Application, Second Board of Appeal, Office of Harmonization for the Internal Market (2004) E.T.M.R. 4 (refusing the registration of the taste of strawberries as used on pharmaceuticals) available at http://oami.europa.eu/ search/legaldocs/la/EN_Refused_index.cfm_(search for Trade mark No. 001452853).

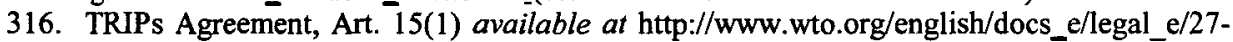
trips.pdf.

317. Case C-283/01, Shield Mark BV v. Kist, 2003 E.C.R. I-14313, OJ C 21, 24.01.2004, p. 4 (2003), available at http://curia.europa.eu/jcms/jcms/j_6/ (search for Case no C-283/01).

318. C-104/01, Libertell Groep BV v. Benelux-Merkenbureau, 2003 E.C.R. I3793, OJ C 146, 21.06.2003, p. 6 (2003) available at $\mathrm{http}: / /$ curia.europa.eu/jcms $/ \mathrm{jcms} / \mathrm{j} \_6 /$ (search for Case no C104/01).

319. As the United States is the last true believer of the common law jurisdictions and the largest economy in the world, it makes a perfect contrast to Civil Law countries. Most other common law countries such a Great Britain or Canada have already moved their trademark systems closer to Civil Law countries. Australia may be an exception to this. In Australia, although nontraditional trademarks like color are registered and enforced, they remain a "relatively rare beast." Campbell Thompson \& Bill Ladas, How Green Is My Trade Mark? Woolworths v. BP, 29 EUR. INTELL. PROP. REV. 29, 29 (2007). 
rights in the United States are derived from priority of use, not registration. ${ }^{320}$ It is this use that makes the federal regulation of trademarks constitutional in the United States. ${ }^{321}$ Trademarks are not writings. ${ }^{322}$ Therefore, the Patent and Copyright Clause of the United States Constitution does not apply. Trademarks may by regulated by Congress under the Commerce Clause. ${ }^{323}$ For there to be commerce which Congress can regulate, there must be use in interstate commerce. Although there are advantages to obtaining a federal registration in the United States, ${ }^{324}$ the trademark right itself subsists upon use of a mark, not on registration. $^{325}$

320. In re Trade-Mark Cases, 100 U.S. 82, 94 (1879); United Drug Co. v. Theodore Rectanus Co., 248 U.S. 90, 97-100 (1918).

321. Jerome Gilson, Karin Green, \& Anne Gilson LaLonde, 1-3 Gilson ON TradEMARKs § 3.02 (Matthew Bender); 15 U.S.C. $\$ 1052$ (d). Proctor and Gamble Company v. Johnson and Johnson, Inc. 485 F. Supp. 1185 (S.D.N.Y. 1980) aff'd at 636 F.2d 1203 (2d Cir. 1980); In re Compagnie Generale Maritime, 993 F.2d 841, 854 (CAFC 1993) ("The 'use in commerce' requirement is the Constitutional basis for enactment of the Lanham Act, . . .) (Judge Nies, dissenting); Buti v. Perosa, S.R.L., 139 F.3d 98, 102 (2d Cir. 1998) cert. denied, 525 U.S. 826, 119 S. Ct. 73, 142 L. Ed. 2d 57 (1998)("use in commerce" requirement of the Lanham Act is simply a jurisdictional predicate to any law passed by Congress under the Commerce Clause. The "history and text of the Lanham Act show that 'use in commerce' reflects Congress's intent to legislate to the limits of its authority under the Commerce Clause") (quoting United We Stand America, Inc. v. United We Stand, America New York, Inc., 128 F.3d 86, 92 (2d Cir. 1997)).

322. See In re Trade-Mark Cases, 100 U.S. 82, 94 (1879) (discussing difference in a writing and a trademark).

323. U.S. ConsT. art. I, \& 8, cl. 3 .

324. 1) Notice: Perhaps one of the most significant reasons to register a trademark regards notice of rights. Section 22 (15 U.S.C. \$1072) provides for constructive notice of claimed rights under the Lanham Act. That is, once a trademark is registered, all would-be infringers are charged with knowledge of the registration and the benefits derived thereunder. In litigation, this could have a significant impact on the outcome of any given case. See Melissa E. Roth, Something Old, Something New, Something Borrowed, Something Blue: A New Tradition In Nontraditional Trademark Registrations, 27 CARDOZO L. REV. 457, 469-471 (2005) (registration provides constructive notice). 2) Deterrence: Closely related to the notice function, trademark registration owners can claim use of the $®$ symbol on goods or services. Although not precisely documented as such, it is thought that use of the ${ }^{\circledR}$ symbol provides some deterrence to infringers. See Philip J. Greene, Trademark Counsel in the Federal Government -- A Practitioner's Perspective, 86 J. PAT. \& TRADEMARK OfF. SOC'Y 361, 375 (2004) ("the (R) symbol adjacent to the mark will help dispel the notion that government marks are in the public domain"). 3) National protection: Once a trademark is registered, the owner of that registration can claim national priority. If this registration is based on an intent to use a mark, that priority date reverts back to the actual application date of the registration. See Laurinda L. Hicks \& James R. Holbein, Convergence of National Intellectual Property Norms in International Trading Agreements, 12 AM. U.J. INT'L L. \& POL'Y 769, 777 ("Although federal registration grants substantive and procedural rights to the trademark owner, the absence of such federal registration does not place the mark in the public domain."). 4) Incontestability: Once a registered trademark is used for five consecutive years, the owner of that registration can claim the registration has become "incontestable" under Section 15 of the Lanham Act. As will be seen, this, too, can provide many positive consequences for the plaintiff/trademark registration owner. The stakes over incontestability went up remarkably in 2009 when the Eighth Circuit held that when a mark became incontestable, it so changed the circumstances that collateral estoppel did not prevent the plaintiff from suing the defendant a second time on the same operative facts. B\&B Hardware, Inc. v. Hargis Indus., 569 F.3d 383, 388 (8th Cir. 2009). 5) Cybersquatting: It is far easier to establish a bona fide commercial interest in a registered trademark for purposes of 
As we adequately demonstrated in the Qualitex decision, it does not need an act of Congress to expand the notion of trademark protection to nontraditional trademarks. ${ }^{326}$ In that case, the Supreme Court held that "any" appellation of source could be claimed as a trademark as long as there was secondary meaning and that there ought to be no per se exclusion of any trademark subject matter. ${ }^{327}$ Therefore, as was stated earlier, after the Qualitex case, trademark applications for nontraditional trademarks in the United States exploded. ${ }^{328}$ Congress did not amend the Lanham Act. There was one judicial holding by the Supreme Court and the entire scenario for nontraditional trademarks changed. ${ }^{329}$

In the United States there may be a litmus test used to attempt to exclude activist judges where judges must swear to the "application of law" god and forgo the "judges making law" devil, ${ }^{330}$ but there is plenty of evidence that United States judges have no choice but to make law. ${ }^{331}$ As in the Qualitex case,

both the Uniform Dispute Resolution Policy (governing the transfer of domain names) and the Anti-cybersquatting Consumer Protection Act (governing the same but in an Article III-style court of law). Bringing a cause of action under either of these provisions based on a registered trademark substantially minimizes the burden of proving the complainant or plaintiff had a commercial interest in the mark. Furthermore, if a trademark is registered, it makes it exceedingly difficult (especially under the UDRP) to make the requisite showing that subsequently registering that trademark as a domain name was done in bad faith. See Adam Silberlight, www. How to Be A Master of Your Domain.com: A Look at The Assignment of Internet Domain Names Under Federal Trademark Laws, Federal Case Law, And Beyond, 10 ALB. L.J. SCl. \& TeCH. 229 (2000) (discussing the application of trademark laws to cybersquatting claims). 6) Evidentiary advantages: Section 33(b) (15 U.S.C. $\$ 1115$ (b)) provides, in relevant part, as follows: "To the extent that the right to use the registered mark has become incontestable ... the registration shall be conclusive evidence of the validity of the registered mark and of the registration of the mark, of the registrant's ownership of the mark, and of the registrant's exclusive right to use the registered mark in commerce ..." (Emphasis added.) That is, incontestable status provides the owner with "conclusive evidence" of the validity of the mark and other advantages. This, too, in a close call in a litigation setting has the potential of dictating outcomes. 7) There are many other advantages to registration, including barring infringing goods by evoking part of Customs law to certain advantages regarding counterfeiting. Although significant in their own right, neither of these topics plays a significant role in these materials.

325. In re Trade-Mark Cases, 100 U.S. 82, 94 (1879).

326. Qualitex Co. v. Jacobson Products Co., Inc., 514 U.S. 159 (1995).

327. Id.

328. See supra notes 9-22 and accompanying text.

329. See supra pp. 9-22 and accompanying text.

330. Confirmation Hearing, supra $n$. 270.

331. William E. Forbath, The Shaping of The American Labor Movement, 102 HARV. L. REV. 1111 (1989); Jean-Luc Piotraut, An Author's Rights-Based Copyright Law: The Fairness and Morality of French and American Law Compared, 24 CARDOZO ARTS \& ENT. L.J. 549, 597 (2006) ("Examples of judge-made law in [copyright law] include: 'a right to disclose or first publish a work; a right of modification or withdrawal of a work (normally subject to an obligation to indemnify aggrieved parties in respect of financial losses); a right to prevent excessive criticism of a work; and a right against false attribution.") (quoting Gerald Dworkin, The Moral Right of the Author: Moral Rights and the Common Law Countries, 19 ColuM.-VLA J.L. \& ARTS 229, 230 (1995)); Herbert C. Wamsley, The Rulemaking Power of the Commissioner of Patents and Trademarks (pt. 2), 64 J. PAT. OFF. Soc'Y 539, 557 (1982) ("The fact that PTO rules must be consistent with judge-made law as well as statutory law limits considerably the Commissioner's power to promulgate substantive rules, because a massive amount of judge-made law exists in the 
the Supreme Court may not have made a law allowing for nontraditional trademarks; however, if only 54 nontraditional trademarks were filed in nearly 50 years before the Qualitex decision and 352 were filed in the 15 years after that case, it is hard to argue that the result of the Qualitex case was anything other than making law. Applying the old statute in a new way made law. That is all that happened in the Qualitex case.

Of course, in the United States, there is general pleading for lawsuits, ${ }^{332}$ discovery is liberal ${ }^{333}$ and there are jury trials. Today, roughly one half of all trademark trials are before juries. ${ }^{334}$ In addition, surveys are greatly used and relied upon. ${ }^{335}$ In some district courts, if a litigant does not proffer a survey it is presumed that the survey would not support the proposition that is being argued. ${ }^{336}$ Surveys in the United States have become a more precise science. These are not general opinion surveys, which are not worth much. Good trademark surveys establish foundation, establish that the respondent is knowledgeable about the questions asked and can be submitted into evidence as reliable. $^{337}$

The trademark in the United States is never owned. ${ }^{338}$ In the United States, only the right to exclude others to the extent the mark is used and as long as the mark is used would be considered a property right. A property right of exclusion

patent and trademark field.").

332. Fed. R. Civ. P. 8(a)(2).

333. Fed. R. Civ. P. 26.

334. Mitchell Study on Trademark Litigation, Graph B: Total Infringement Claims Established/Not Established (2008), http://www.wmitchell.edu/intellectual-property/files/WMTMStudy-GraphB.pdf.

335. See generally, Phyllis J. Welter, Trademark Surveys (1998).

336. World Wrestling Fed'n. Entm't, Inc. v. Big Dog Holdings, Inc., 280 F. Supp. 2d 413 (WD Penn. 2003) ("The Court is aware that WWE is not legally required to conduct a confusion survey. Such a failure, particularly when the trademark owner is financially able, justifies an inference 'that the plaintiff believes the results of the survey will be unfavorable."') (quoting Charles Jacquin et Cie, Inc. v. Destileria Serralles, Inc., 921 F.2d 467, 475 (3d Cir. 1990)).

337. Dan Sarel \& Howard Marmorstein, The Effect of Consumer Surveys and Actual Confusion Evidence in Trademark Litigation: An Empirical Assessment, 99 TRADEMARK REP. 1416 (2009); E. Deborah Jay, Genericness Surveys in Trademark Disputes: Evolution of Species, 99 TRADEMARK REP. 1118 (2009); Richard J. Leighton, Using Daubert-Kumho Gatekeeping to Admit and Exclude Surveys in Lanham Act Advertising and Trademark Cases, 92 TRADEMARK REP.743, 781 (2002) (discussing reliability of surveys); Alex Simonson, Surveys of Trademark Confusion: Basic Differences, 5 INTELL. PROP. STRATEGIST 1 (1998) (discussing ways to critique surveys); William G. Barber, How to Do a Trademark Dilution Survey (or Perhaps How Not to Do One), 89 TRADEMARK REP. 616 (1999); Gabriel M. Gelb and Betsy D. Gelb, Internet Surveys for Trademark Litigation: Ready or Not, Here They Come, 97 TradEMARK ReP. 1073 (2007); Dan Sarel \& Howard Marmorstein, Designing Confusion Surveys for Cyberspace Trademark Litigation: The Admissibility vs. Weight Debate, Vol. 14 No. 9 Intellectual Property \& Technology Law JOURNAL 12 (2002); Keith M. Stolte, Remedying Judicial Limitations on Trademark Remedies: Monetary Relief Should Not Require Proof of Actual Confusion, 75 DENV. U.L. REv. 229, 249-50 (1997); Jacob Jacoby, A Critique of Rappeports 'Litigation Surveys-Social 'Science' as Evidence", 92 TRADEMARK REP. 1480 (2002); Vincent N. Palladino, Assessing Trademark Significance: Genericness, Secondary Meaning and Surveys, 92 TRADEMARK REP. 857 (2002).

338. United Drug Co. v. Theodore Rectanus Co., 248 U.S. 90, 96-98 (1918). 
and a property right to a corporeal thing are very different things. In the United States the trademark right is a right of exclusion; in Civil Law nations a trademark is a corporeal thing that is owned.

The United States system of trademark protection is based on fair competition. ${ }^{339}$ Trademark law is one subset of unfair competition law. It has its roots in the English tort of deceit where the deceived consumer had standing to sue, not an aggrieved trademark holder. ${ }^{340}$ The trademark laws in the United States are founded on the notion that the consumer has a right to be free of deception. ${ }^{341}$

In the United States today, there are three competing interests that need to be simultaneously balanced. The first is this consumer's right to be free of deception. ${ }^{342}$ However, if the system over-protects the consumer, trademark holders may use trademarks less and thereby society would not receive that benefit of trademark use. Consumers' search costs would go up if trademark holders used trademarks less often and consumers would pay more for their goods and services. ${ }^{343}$

Therefore, the rights of trademark holders also must be balanced in this equation. Trademark holders must receive adequate incentive to continue to use trademarks. ${ }^{344}$ Trademark holders need to feel that their trademarks are appropriately protected and enforced. Trademark holders need to continue to invest in trademarks so that society's search costs are lessened and society can take advantage of the short-cut function that trademarks play. ${ }^{345}$

As a subset of unfair competition law, trademark law and policy also must include the rights of third parties and their ability to compete. ${ }^{346}$ If trademark rights are too strong in the United States, third parties will not be able to compete. Third parties' costs of market access would go up if they have to defend too many law suits or if they have to work too hard to clear trademarks before using the marks. ${ }^{347}$ Additionally, third parties would suffer from too

339. Moseley v. V Secret Catalogue, Inc., 537 U.S. 418, 428 (2003).

340. J. Thomas McCarthy, 1 McCarthy on Trademarks and Unfair Competition $\S 5: 2$ (1996 4th ed.).

341. Id.

342. BellSouth Advertising \& Publishing Corp. v. Real Color Pages, Inc., 792 F. Supp. 775, 780-81 (M.D. Fla. 1991).

343. William M. Landes \& Richard A. Posner, The Economics of Trademark Law, 78 TRADEMARK ReP. 267 (1986).

344. Id.

345. Id.

346. See Kenneth L. Port, The Congressional Expansion of American Trademark Law: A Civil Law System in the Making, 35 WAKE FOREST L. REV. 827, 831 (2000) ("The economic rationale for trademark protection is undermined [by expansion of rights] because the expansion actually increases total transaction costs rather than being, at least, cost neutral . . . [T] he expansion undercuts the legal rationale for trademark protection because it tips the scales in favor of protecting the goodwill of the trademark owner rather than balancing the interests of the consumer to be free from confusion and third parties' right to compete.").

347. Kenneth L. Port, Trademark Extortion: The End of Trademark Law, 65 WASH. \& LEE L. 
strong protection of trademarks because the range of available marks that third parties might use would shrink.

All three of these interests need to be balanced. Historically, the United States has been focused on the equality of each of these three pillars of trademark protection. The data on reported trademark cases seems to bear out this fact. In the last 60 years, trademark claimants have prevailed in their claims of infringement $50 \%$ of the time. ${ }^{348}$ This rate is shrinking. Today, fewer trademark claimants prevail in their claims of infringement than they did just a decade ago. ${ }^{349}$

Therefore, there is a critical gap in the theoretical justification of protecting trademarks in Civil Law countries compared to the United States. This theoretical difference makes harmonization of any sort difficult. Even if the doctrine is harmonized, the underlying theory will remain diverse. This distinction is why trademark harmonization has not been successful to date. In order to succeed, the doctrine and the theory must be harmonized.

\section{The Normative CaSe Against Nontraditional Marks}

Normatively, with few exceptions, nontraditional trademarks do not satisfy the expectations we have for trademarks. Even doctrinally, there is little justification for the protection of nontraditional trademarks. Nontraditional trademarks are functional. Nontraditional trademarks do not act as indicators of source. Nontraditional trademarks are byzantine elements of a good or service. They do not indicate that the good or service comes from a consistent source. Even though nontraditional trademarks have recognized a huge spike postQualitex, nontraditional trademarks are very rarely found valid and infringed by Article III style court.

Jacobson, the losing party in Qualitex $\mathcal{V}$. Jacobson, actually provided the most the perfect objections to all of nontraditional trademarks, not just color. ${ }^{350}$ These are addressed below.

\section{A. Sense Depletion}

Jacobson argued that to protect a color would ultimately limit the number of colors available for a competitor to use. ${ }^{351}$ When applying this notion to nontraditional marks, we might call it sense depletion.

\footnotetext{
REV. 585 (2008).

348. Mitchell Study on Trademark Litigation, Graph B: Total Infringement Claims Established/Not Established (2008), http://www.wmitchell.edu/intellectual-property/files/WMTMStudy-GraphB.pdf.

349. See Mitchell Study on Trademark Litigation, Graph C: Infringement Claims Established/Not Established by Decade (2008) http://www.wmitchell.edu/intellectualproperty/files/WM-TMStudy-GraphC.pdf (graphically representing claims established by decade).

350. Qualitex Co. v. Jacobson Products Co., Inc., 514 U.S. 159 (1995)

351. Id. at 168 .
} 
When the human brain can only remember sixteen scents for a long period of time, ${ }^{352}$ allowing anyone to register a smell seems to work great hardship, a great depletion, of that sense. Although there are many sounds available in the world, allowing anyone to exclude others from the use of sound would inappropriately drive up transaction costs without the related benefit to society of the trademark use. ${ }^{353}$ That is, making a product sound attractive is decoration. Decoration is considered to be aesthetically functiona $\mathrm{l}^{354}$ and therefore not protected.

It seems that the sense depletion theory is very important in field of nontraditional trademarks. Allowing them to be protected depletes the field and does not result in the expected reduction in transaction costs.

\section{B. Sense Confusion}

With sense confusion, we are worried about articulating a standard by which a use could be judged as infringing or not infringing. All Circuits have come up with tests to be applied to traditional marks. ${ }^{355}$ This is known as the likelihood of confusion analysis. ${ }^{356}$

With nontraditional marks, what will be the test? Simple variations of the nontraditional trademark might result in big differences in perception because nontraditional trademarks rely on senses that are arbitrary and not well understood. These senses are not consistent between people. They, in fact, are inherently unreliable. ${ }^{357}$

With a traditional mark, it can be projected to a jury. The jury can look at the alleged infringing mark, such as KOKE and compare it to the word COKE. ${ }^{358}$ The jury can think about whether KOKE infringes COKE. It does not have to agree with what COKE is, how it should be perceived, or how it is to be known. Those are givens in traditional trademarks.

With nontraditional marks, the jury has to first decide what the mark is before it can go on to decide if the mark has been infringed. When nontraditional trademarks are invoked, reasonable jurors would think differently of the nontraditional trademark. No two jurors would ever agree on the scent of a mark or the motion of a mark. These things are subjective and variable. When

352. See Churovich, supra n. 187, at 302 .

353. See William M. Landes \& Richard A. Posner, The Economics of Trademark Law, 78 TRADEMARK REP. 267, 270 (1986) (discussing costs and benefits of trademarks generally).

354. W.T. Rogers Co. v. Keene, 778 F.2d 334, 339-40 (7th Cir. 1985) (commercial need precludes trademark protection); see also Jerre B. Swann, The Design of Restaurant Interiors - $A$ New Approach to Aesthetic Functionality, 76 TRADEMARK REP. 408, 408 (1986) ("Primarily attractive features serve 'other than a trade-mark purpose."'); 1-2 GILSON ON TRADEMARKS $\S 2.11$ (“...consumers may not perceive certain nontraditional marks as trademarks at all. They may see them as merely decorative, as an inherent part of the product or as an attempt to amuse, rather than as indicating the source of the goods").

355. 5-5 GILSON ON TRADEMARKS $§ 5.02$.

356. 1-1 GILSON ON TRADEMARKS $§ 1.04$.

357. See, e.g., supra Parts VI-VII.

358. Coca-Cola Co. v. Koke Co. of Am., 254 U.S. 143 (1920). 
a scent mark is not perceived the same between two people or even by one person given weather patterns, etc. these marks seem too indeterminate to warrant trademark protection. There would be far too much sense confusion to make sense of these trademarks.

\section{Ability to Act as a Trademark}

The biggest worry with nontraditional trademarks is whether they are actually acting as a trademark at all. Consider, for example, the Yamaha personal watercraft spray. Is this so-called trademark acting to identify Yamaha personal watercrafts or is it a nifty product feature that people buy because of the product feature, not because they are relying on it to identify source. Yet again, we bump into the notion of aesthetic functionality.

With many nontraditional marks, one does not have to enter the murky lands of aesthetic functionality to oppose a trademark. Most nontraditional trademarks do not pass the functionality test. ${ }^{359}$ Most nontraditional marks are initially refused registration because of this doctrine. Nontraditional trademarks play a role in dictating the function of a product. Many of these relate to human senses that we do not clearly understand. One court denied trademark protection for the color of boat engines. ${ }^{360}$ That court held that black motors worked to make an object look smaller and therefore was playing a function of the product. ${ }^{361}$

If the nebulous notion of a color contributing to our size perception of the product is worthy of analysis, I suggest that we do not understand the role nontraditional trademarks is playing in our purchasing decisions. Do we buy the black engine because we think engine should be black or because it identifies source? Most likely, we have an inconsistent image in our minds about what color things should be or how they should smell, etc. When Mrs. Clark makes her skunks smell like plumeria, ${ }^{362}$ we are not only relieved, we like it. We do not buy the skunks because the smell indicated source. Plumeria is a very fine scent. We buy the skunks because we like the smell of plumeria, not because it indicates source.

As such, nontraditional trademarks do not play the role of indicating source and they cannot. Nontraditional trademarks merely make a product more attractive. The product is purchased by buyers not because of the source denoting capacity of the nontraditional mark but rather because of an extremely inconsistent, subjective notion of what is "good" or "attractive."

359. See, e.g., Traffix Devices, Inc. v. Marketing Displays, Inc., 532 U.S. 23 (dual-spring design is a functional feature) (2001).

360. Brunswick v. Corp. v. British Seagull Ltd, 35 F.3d 1527 (Fed. Cir. 1994)

361. Id. at 1529 .

362. See supra notes $180-86$ and accompanying text. 


\section{Is it Worth it?}

All this raises a very important question: is it worth it? I submit that it is not. Nontraditional trademarks are much harder to get than traditional marks. On average, nontraditional marks take more than 30 months to be registered. ${ }^{363}$ Traditional marks take far less time. ${ }^{364}$ Nearly half of all nontraditional trademarks applied for registration no longer exist. ${ }^{365}$ The applications have gone abandoned or the registrations have been cancelled for nonuse. Courts do not enforce nontraditional trademarks.

Therefore, although obtaining a registration for a nontraditional mark is possible in the United States, it is not worth it. It is not worth it from the trademark claimants' viewpoint as it takes so long and most are lost or abandoned. It is not worth it from society's point of view as allowing this protection does not reduce transaction costs. Society gets nothing in return for allowing the protection of nontraditional trademarks. Nontraditional marks do not play the same role of reducing transaction costs so that our products cost less. ${ }^{366}$ Nontraditional trademarks merely adorn and beautify our products. Although I'm all in favor of pretty goods, pretty is not a trademark. As such, trademark protection for nontraditional marks is not worth the investment.

\section{CONCLUSION}

There must be a reason why trademark harmonization has been so difficult to realize. The world knows that a lack of harmonization contributes, in significant ways, to the cost of doing business internationally. Harmonizing trademark laws would be good for all. Yet, it has remained elusive.

The reason trademark doctrine has not been harmonized is because the underlying theory of trademark protection between the Civil Law world on one hand and the Common Law world, primarily the United States, on the other hand are so disparate.

The protection of nontraditional trademarks in the United States is an extreme manifestation of this divergence. With one holding from one Supreme Court decision, nontraditional trademark applications for registration increased exponentially. That decision merely said that there were no per se restrictions on the subject matter of trademarks. "Any" meant any.

Civil Law jurisdictions do not have that flexibility. As positivists, they must wait for their legislatures to enumerate the specific scope of trademark protection. Their Examiners have very little experience in examining nontraditional trademarks, to the extent applications are received.

363. See infra app. D.

364. See supra notes $159-162$ and accompanying text.

365. See infra app. C.

366. See supra notes 54-56 and accompanying text. 
Therefore, until the theoretical orientation of trademark policy between the Civil Law and the United States is harmonized, trademark harmonization efforts will remain elusive. The United States exacerbates this issue by protecting "any" indicator source. Civil Law countries make this exacerbation worse by attempting to harmonize to the standard of protecting nontraditional trademarks, meanwhile adhering to the Civil Law notion of trademark protection. That is, this doctrinal harmonization will not be meaningful because it affects so few trademarks and the trademark jurisprudence remains disparate. As such, transaction costs incurred because of disparate trademark systems around the world will not be reduced. This is truly harmonization that simply does not matter.

The protection of nontraditional trademarks is further rendered suspect in the United States by the fact that there has been such a spike in trademark applications for nontraditional trademarks post-Qualitex, but the rate of litigation has remained nearly static. That is, trademark owners are interested in applying to register nontraditional marks, but they are not interested in enforcing them. This raises the question of why? If trademark holders are interested in registering nontraditional marks, why are they not enforcing them? When they do, they only succeed $1 / 3$ of the time.

If, for example, Japan harmonizes to the American standard of protecting nontraditional trademarks, Japan will be making several mistakes. The first mistake is to think that nontraditional trademarks add up to something in the United States. They do not. Even though Qualitex held that color alone could be protected and an explosion of interest developed regarding nontraditional trademarks, the numbers still do not add up to much. The second mistake is to believe that other countries are engaged in the protection of nontraditional trademarks based on the survey from WIPO. They are not. Even though the Singapore Treaty explicitly addresses nontraditional marks, they remain a very rare entity in Civil Law systems. Finally, if Japan merely adopts a nontraditional trademark system without thought to the underlying theory of trademark protection, the harmonization will be empty.

These mistakes work to prove the point: real trademark harmonization has a long way to go. We should not get distracted by meaningless claims like protecting (or not) Frank Ogden's DNA sequence. 


\begin{tabular}{|c|c|c|}
\hline \multicolumn{3}{|c|}{ HPPENDIX A } \\
\hline \multirow{2}{*}{\multicolumn{3}{|c|}{ 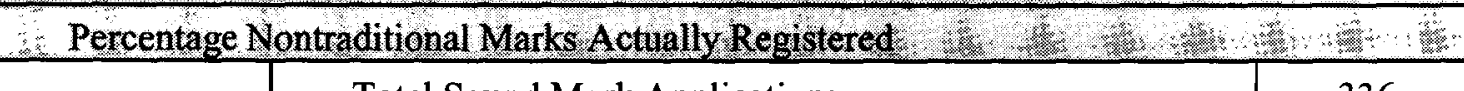 }} \\
\hline & & \\
\hline \multirow[t]{3}{*}{ Sound } & Total Registered Sound Marks & 171 \\
\hline & Percentage Total Sound Marks Registered & $50.89 \%$ \\
\hline & Total Scent Mark Applications & 28 \\
\hline \multirow[t]{3}{*}{ Sent Scent } & Total Registered Scent Marks & 12 \\
\hline & Percentage Total Scent Marks Registered & $42.86 \%$ \\
\hline & Total Color Mark Applications & 345 \\
\hline \multirow[t]{3}{*}{ Color } & Total Registered Color Marks & 242 \\
\hline & Percentage Total Color Marks Registered & $70.14 \%$ \\
\hline & Total Taste Mark Applications & 9 \\
\hline \multirow[t]{3}{*}{ Taste } & Total Registered Taste Marks & 0 \\
\hline & Percentage Total Taste Marks Registered & $0.00 \%$ \\
\hline & Total Tactile Mark Applications & 5 \\
\hline \multirow[t]{3}{*}{ Tactile } & Total Registered Tactile Marks & 1 \\
\hline & Percentage Total Tactile Marks Registered & $20.00 \%$ \\
\hline & Total No Description Mark Applications & 16 \\
\hline \multirow[t]{3}{*}{ NoDesceription } & Total Registered No Description Marks & 1 \\
\hline & Percentage Total No Description Marks Registered & $6.25 \%$ \\
\hline & Total Other Mark Applications & 5 \\
\hline \multirow[t]{3}{*}{ Other } & Total Registered Other Marks & 2 \\
\hline & Percentage Total Other Marks Registered & $40.00 \%$ \\
\hline & Total Motion Applications & 18 \\
\hline \multirow[t]{3}{*}{ Motion } & Total Registered Motion Marks & 13 \\
\hline & Percentage Total Motion Marks Registered & $72.22 \%$ \\
\hline & Total Hologram Applications & 19 \\
\hline
\end{tabular}




\begin{tabular}{l|l|l|}
\hline Hologram & Total Registered Hologram Marks & 11 \\
\hline & Percentage Total Hologram Marks Registered & $57.89 \%$ \\
\cline { 2 - 3 } & Total Nontraditional Mark Applications (incl.pending) & 781 \\
\hline & Total Registered Nontraditional Marks & 454 \\
\hline & Percentage Total Nontraditional Marks Registered & $57.89 \%$ \\
\hline
\end{tabular}




\begin{tabular}{|c|c|c|}
\hline \multicolumn{3}{|c|}{ EAPENDIXB } \\
\hline \multicolumn{3}{|c|}{ Percentage Pending Nontraditional Mark Applications } \\
\hline & Total Sound Mark Applications & 336 \\
\hline \multirow[t]{3}{*}{ Sound } & Total Pending Sound Marks & 52 \\
\hline & Percentage Total Sound Marks Pending & $15.48 \%$ \\
\hline & Total Scent Mark Applications & 28 \\
\hline \multirow[t]{3}{*}{ Scent } & Total Pending Scent Marks & 6 \\
\hline & Percentage Total Scent Marks Pending & $21.43 \%$ \\
\hline & Total Color Mark Applications & 345 \\
\hline \multirow[t]{3}{*}{ Color } & Total Pending Color Marks & 1 \\
\hline & Percentage Total Color Marks Pending & $0.29 \%$ \\
\hline & Total Taste Mark Applications & 9 \\
\hline \multirow[t]{3}{*}{ Taste } & Total Pending Taste Marks & 0 \\
\hline & Percentage Total Taste Marks Pending & $0.00 \%$ \\
\hline & Total Tactile Mark Applications & 5 \\
\hline \multirow[t]{3}{*}{0. Tactile } & Total Pending Tactile Marks & 1 \\
\hline & Percentage Total Tactile Marks Pending & $20.00 \%$ \\
\hline & Total No Description Mark Applications & 16 \\
\hline \multirow[t]{3}{*}{ No Description: } & Total Pending No Description Marks & 2 \\
\hline & Percentage Total No Description Marks Pending & $12.50 \%$ \\
\hline & Total Other Mark Applications & 5 \\
\hline \multirow[t]{3}{*}{ Other } & Total Pending Other Marks & 2 \\
\hline & Percentage Total Other Marks Pending & $40.00 \%$ \\
\hline & Total Motion Applications & 18 \\
\hline \multirow[t]{2}{*}{ Motion } & Total Pending Motion Marks & 2 \\
\hline & Percentage Total Motion Marks Pending & $11.11 \%$ \\
\hline
\end{tabular}




\begin{tabular}{|c|c|c|}
\hline & Total Hologram Applications & 19 \\
\hline (x) & Total Pending Hologram Marks & 3 \\
\hline & Percentage Total Hologram Marks Pending & $15.79 \%$ \\
\hline
\end{tabular}




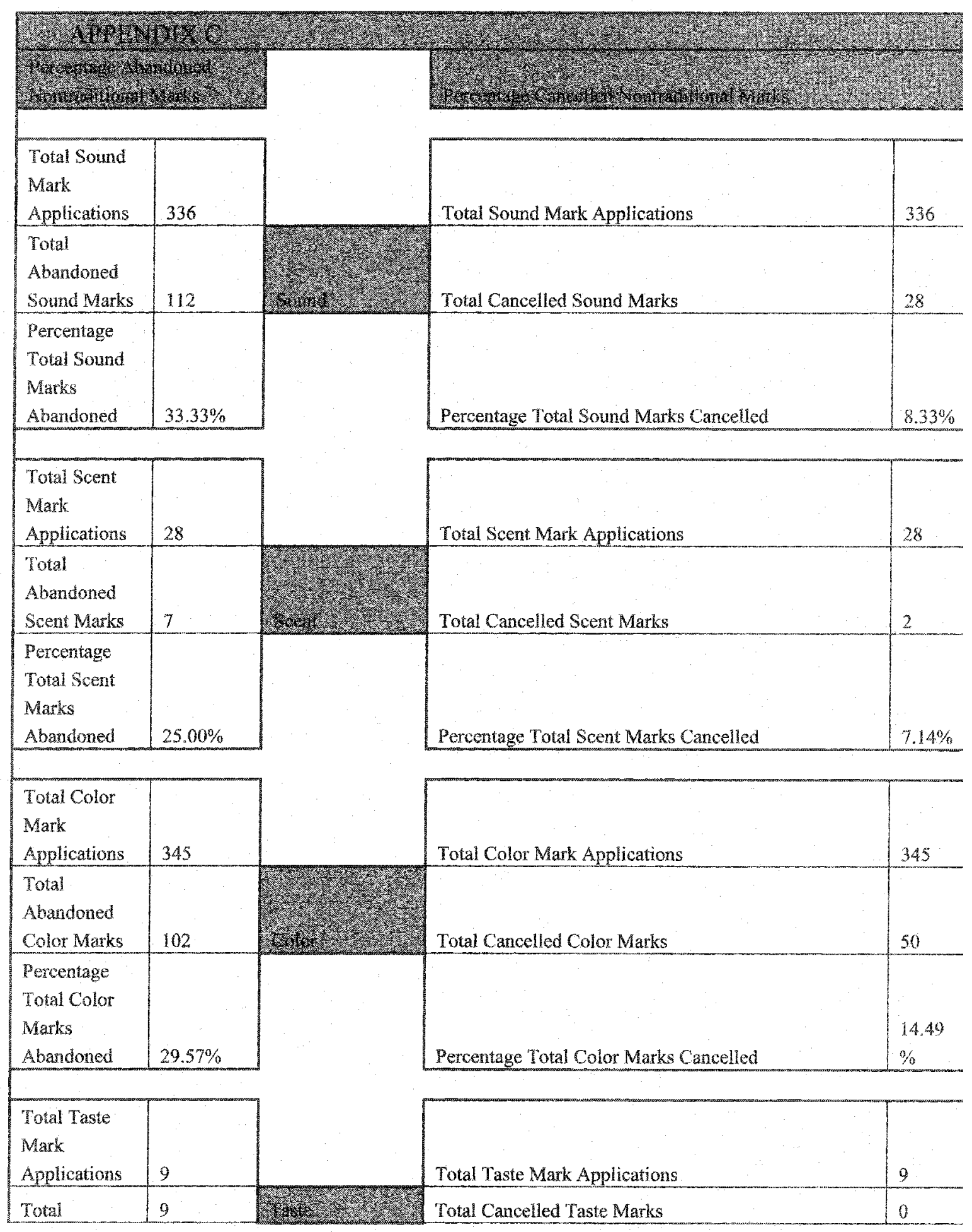




\begin{tabular}{|c|c|c|c|c|}
\hline $\begin{array}{l}\text { Abandoned } \\
\text { Taste Marks }\end{array}$ & & 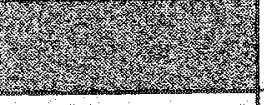 & & \\
\hline $\begin{array}{l}\text { Percentage } \\
\text { Total Taste } \\
\text { Marks } \\
\text { Abandoned }\end{array}$ & $100.00 \%$ & & ${ }^{2}, \quad(2)$ & $0.00 \%$ \\
\hline $\begin{array}{l}\text { Total Tactile } \\
\text { Mark } \\
\text { Applications }\end{array}$ & 5 & & Total Tactile Mark Applications & 5 \\
\hline $\begin{array}{l}\text { Total } \\
\text { Abandoned } \\
\text { Tactile Marks }\end{array}$ & 3 & 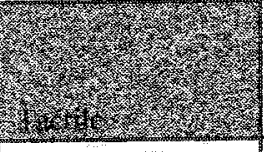 & Total Cancelled Tactile Marks & 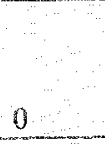 \\
\hline $\begin{array}{l}\text { Percentage } \\
\text { Total Tactile } \\
\text { Marks } \\
\text { Abandoned }\end{array}$ & $60.00 \%$ & & Percentage Total Tactile Marks Cancelled & $0.00 \%$ \\
\hline $\begin{array}{l}\text { Total No } \\
\text { Description } \\
\text { Mark } \\
\text { Applications }\end{array}$ & 16 & & Total No Description Mark Applications & 16 \\
\hline $\begin{array}{l}\text { Total } \\
\text { Abandoned } \\
\text { No } \\
\text { Description } \\
\text { Marks } \\
\end{array}$ & 11 & 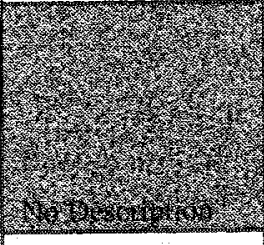 & Total Cancelled No Description Marks & a \\
\hline $\begin{array}{l}\text { Percentage } \\
\text { Total No } \\
\text { Description } \\
\text { Marks } \\
\text { Abandoned }\end{array}$ & $68.75 \%$ & & Percentage Total No Description Marks Cancelled & $0.00 \%$ \\
\hline $\begin{array}{l}\text { Total Other } \\
\text { Makk } \\
\text { Applications }\end{array}$ & 5 & & Total Other Mark Applications & 5 \\
\hline $\begin{array}{l}\text { Total } \\
\text { Abandoned } \\
\text { Other Marks }\end{array}$ & 1 & 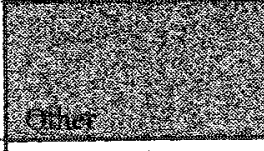 & Total Cancelled Other Marks & 1 \\
\hline $\begin{array}{l}\text { Percentage } \\
\text { Total Other } \\
\text { Marks } \\
\text { Abandoned }\end{array}$ & $20.00 \%$ & & Percentage Total Other Marks Cancelled & 20.00 \\
\hline
\end{tabular}




\begin{tabular}{|c|c|c|c|}
\hline $\begin{array}{l}\text { Total Motion } \\
\text { Applications }\end{array}$ & 18 & Total Motion Applications & 18 \\
\hline $\begin{array}{l}\text { Total } \\
\text { Abandoned } \\
\text { Motion Marks }\end{array}$ & 2 & Total Cancelled Motion Marks & 1 \\
\hline $\begin{array}{l}\text { Percentage } \\
\text { Total Motion } \\
\text { Marks } \\
\text { Abandoned }\end{array}$ & $11.11 \%$ & Percentage Total Motion Marks Cancelled & $5.56 \%$ \\
\hline $\begin{array}{l}\text { Total } \\
\text { Hologram } \\
\text { Applications }\end{array}$ & 19 & Total Hologram Applications & 19 \\
\hline $\begin{array}{l}\text { Total } \\
\text { Abandoned } \\
\text { Hologram } \\
\text { Marks } \\
\end{array}$ & 5 & Total Cancelled Hologram Marks & 8 \\
\hline $\begin{array}{l}\text { Percentage } \\
\text { Total } \\
\text { Hologram } \\
\text { Marks } \\
\text { Abandoned }\end{array}$ & $26.32 \%$ & Percentage Total Hologram Marks Cancelled & $\begin{array}{l}42.11 \\
\%\end{array}$ \\
\hline
\end{tabular}




\begin{tabular}{|c|c|}
\hline Sound: Average Time Between Application Filing and Registration & 1.97 \\
\hline Scent: Average Time Between Application Filing and Registration & 2.2 \\
\hline Color: Average Time Between Application Filing and Registration & 3.1 \\
\hline Taste: Average Time Between Application Filing and Registration & NA \\
\hline Tactile: Average Time Between Application Filing and Registration & 1.57 \\
\hline No Description: Average Time Between Application Filing and Registration & 2.37 \\
\hline Other: Average Time Between Application Filing and Registration & 1.86 \\
\hline Motion: Average Time Between Application Filing and Registration & 1.67 \\
\hline Hologram: Average Time Between Application Filing and Registration & 2.47 \\
\hline hin & (x) \\
\hline
\end{tabular}




\begin{tabular}{|c|c|c|}
\hline & Total Sound Mark Annlications. & 336 \\
\hline & Total Post-Qualitex Sound Mark Applications & 295 \\
\hline & Percentage Post-Qualitex Sound Mark Applications & $87.80 \%$ \\
\hline & Total Scent Mark Applications & 28 \\
\hline & Total Post-Qualitex Scent Mark Applications & 27 \\
\hline & Percentage Post-Qualitex Scent Mark Applications & $96.43 \%$ \\
\hline & Total Color Mark Applications & 345 \\
\hline & Total Post-Qualitex Color Mark Applications & 302 \\
\hline & Percentage Post-Qualitex Color Mark Applications & $87.54 \%$ \\
\hline & Total Taste Mark Applications & 9 \\
\hline Stren & Total Post-Qualitex Taste Mark Applications & 9 \\
\hline & Percentage Post-Qualitex Taste Mark Applications & $100.00 \%$ \\
\hline & Total Tactile Mark Applications & 5 \\
\hline the & Total Post-Qualitex Tactile Mark Applications & 5 \\
\hline & Percentage Post-Qualitex Tactile Mark Applications & $100.00 \%$ \\
\hline & Total No Description Mark Applications & 16 \\
\hline 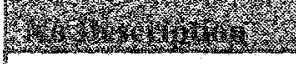 & Total Post-Qualitex No Description Mark Applications & 9 \\
\hline & Percentage Post-Qualitex No Description Mark Applications & $56.25 \%$ \\
\hline & Total Other Mark Applications & 5 \\
\hline 18. & Total Post-Qualitex Other Mark Applications & 5 \\
\hline & Percentage Post-Qualitex Other Mark Applications & $100.00 \%$ \\
\hline & Total Motion Mark Applications & 18 \\
\hline 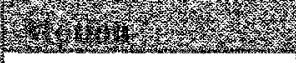 & Total Post-Qualitex Motion Mark Applications & 17 \\
\hline & Percentage Post-Qualitex Motion Mark Applications & $94.44 \%$ \\
\hline
\end{tabular}




\begin{tabular}{|c|c|c|}
\hline & Total Hologram Mark Applications & 19 \\
\hline \multirow{3}{*}{ 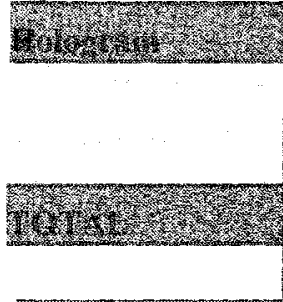 } & Total Post-Qualitex Hologram Mark Applications & 19 \\
\hline & Percentage Post-Qualitex Hologram Mark Applications & $100.00 \%$ \\
\hline & (1) & 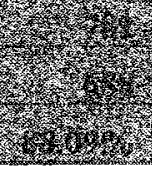 \\
\hline
\end{tabular}


